\title{
Aspergillus fumigatus and Its Allergenic Ribotoxin Asp $f$ I: Old Enemies but New Opportunities for Urine-Based Detection of Invasive Pulmonary Aspergillosis Using Lateral-Flow Technology
}

\author{
Genna Davies ${ }^{1,2}(\mathbb{D})$, Oski Singh ${ }^{2}$, Juergen Prattes ${ }^{3}\left(\mathbb{D}\right.$, Martin Hoenigl $^{3,4}{ }^{(\mathbb{D}}$, Paul W. Sheppard ${ }^{5}$ and \\ Christopher R. Thornton $1,2, *$ (D)
}

Citation: Davies, G.; Singh, O.; Prattes, J.; Hoenigl, M.; Sheppard, P.W.; Thornton, C.R. Aspergillus fumigatus and Its Allergenic Ribotoxin Asp f I: Old Enemies but New Opportunities for Urine-Based Detection of Invasive Pulmonary Aspergillosis Using Lateral-Flow Technology. J. Fungi 2021, 7, 19. https://doi.org/10.3390/jof7010019

Received: 11 November 2020 Accepted: 30 December 2020 Published: 31 December 2020

Publisher's Note: MDPI stays neutral with regard to jurisdictional clai$\mathrm{ms}$ in published maps and institutional affiliations.

Copyright: (C) 2020 by the authors. Licensee MDPI, Basel, Switzerland. This article is an open access article distributed under the terms and conditions of the Creative Commons Attribution (CC BY) license (https:// creativecommons.org/licenses/by/ $4.0 /)$
1 ISCA Diagnostics Ltd., Hatherly Laboratories, Prince of Wales Road, Exeter EX4 4PS, UK; g.davies@exeter.ac.uk

2 Biosciences and MRC Centre for Medical Mycology, Hatherly Laboratories, University of Exeter, Prince of Wales Road, Exeter EX4 4PS, UK; os286@exeter.ac.uk

3 Department of Internal Medicine, Section of Infectious Diseases and Tropical Medicine, Medical University of Graz, A-8036 Graz, Austria; juergen.prattes@medunigraz.at (J.P.); mhoenigl@health.ucsd.edu (M.H.)

4 Division of Infectious Diseases and Global Public Health, University of California San Diego, San Diego, CA 92093, USA

5 Vacye Associates, Lowerdown Cottage, Lowerdown, Bovey Tracey TQ13 9LF, UK; paul.sheppard@vacye.com

* Correspondence: c.r.thornton@exeter.ac.uk

Abstract: Invasive pulmonary aspergillosis (IPA) caused by Aspergillus fumigatus is a life-threatening lung disease of immunocompromised patients. Diagnosis currently relies on non-specific chest $\mathrm{CT}$, culture of the fungus from invasive lung biopsy, and detection of the cell wall carbohydrate galactomannan (GM) in serum or in BAL fluids recovered during invasive bronchoscopy. Urine provides an ideal bodily fluid for the non-invasive detection of pathogen biomarkers, with current urine-based immunodiagnostics for IPA focused on GM. Surrogate protein biomarkers might serve to improve disease detection. Here, we report the development of a monoclonal antibody (mAb), PD7, which is specific to A. fumigatus and related species in the section Fumigati, and which binds to its $18 \mathrm{kDa}$ ribotoxin Asp $f \mathrm{I}$. Using PD7, we show that the protein is secreted during hyphal development, and so represents an ideal candidate for detecting invasive growth. We have developed a lateral-flow device $\left(A f u\right.$-LFD ${ }^{\circledR}$ ) incorporating the $\mathrm{mAb}$ which has a limit of detection of $\sim 15 \mathrm{ng} A s p f \mathrm{I} / \mathrm{mL}$ urine. Preliminary evidence of the test's diagnostic potential is demonstrated with urine from a patient with acute lymphoid leukaemia with probable IPA. The $A f u$-LFD ${ }^{\circledR}$ therefore provides a potential novel opportunity for non-invasive urine-based detection of IPA caused by A. fumigatus.

Keywords: monoclonal antibody; ribotoxin; Asp f I; Aspergillus fumigatus; lateral-flow device; urine

\section{Introduction}

Aspergillus fumigatus is the most important opportunistic mould pathogen of humans, causing a number of different respiratory diseases including aspergilloma, allergic bronchopulmonary aspergillosis (ABPA), chronic pulmonary aspergillosis (CPA), and invasive pulmonary aspergillosis (IPA), a lethal lung disease of mainly immunocompromised individuals, especially those with prolonged neutropenia, haematological malignancies, and bone marrow and solid organ transplants [1,2]. Recently, IPA has also been identified as a complication of influenza known as Influenza-Associated Pulmonary Aspergillosis (IAPA), and as a life-threatening co-infection of critically ill COVID-19 ICU patients known as COVID-19-Associated Pulmonary Aspergillosis (CAPA) [3-7]. The estimated incidence of IPA is $>300,000$ cases / year, with more than $90 \%$ of the $\sim 150,000$ deaths annually caused by A. fumigatus [8]. Detection of IPA is notoriously difficult due to non-specific symptoms, 
and so detection relies on a number of characteristics (host factors, clinical features, and mycological evidence) being present to allow 'probable' or 'proven' diagnosis according to consensus definitions of invasive fungal diseases [9]. Mycological evidence is reliant on slow and insensitive culture of the pathogen from invasive lung biopsy, or detection of biomarkers in serum [10], and/or in bronchoalveolar lavage fluids (BALf) recovered during invasive bronchoscopy [11]. High-resolution computed tomography (HRCT) of the chest can be used for non-invasive visualisation of lung diseases, but abnormalities in a chest-CT are not pathognomonic of IPA, and so can only be used to raise the suspicion of the disease in high-risk patients [12]. While molecular imaging using antibody-guided positron emission tomography (immunoPET) holds enormous promise for the specific and non-invasive detection of Aspergillus lung infections in vivo [12-14], the technology is in its infancy and relies on sophisticated and expensive technology available in a limited number of hospitals only. Consequently, there is a pressing need for the development of diagnostic tests that allow the detection of A. fumigatus biomarkers which are signatures of active infection, which are present in bodily fluids other than serum and invasive BALf, and which are readily accessible in critically ill patients.

Urine is an ideal bodily fluid for the non-invasive detection of pathogen-specific biomarkers. The human urinary proteome contains more than 1500 proteins [15], and changes in urine protein components and concentrations can signify the development of diseases detectable via the transmission of antigens from blood into urine through glomerular filtration of plasma [16]. Based on this principle, a number of immunoassays have been developed for the urine-based detection of bacterial [17], parasitic [18-20], and fungal infections [21,22]. Recently, a lateral-flow assay (LFA) was reported that detects fragments of Aspergillus carbohydrate in the urine of IPA patients [23]. However, this test and other LFA and ELISA tests for the disease [2] rely on the detection of the same polysaccharide biomarker, the cell wall carbohydrate galactomannan (GM). Detection of Aspergillus antigens in urine other than GM might serve to improve IPA diagnosis by allowing a combination biomarker approach to disease detection.

Alternative antigen biomarkers of IPA in urine have been reported previously [1,2], and include an $18 \mathrm{kDa}$ protein secreted by A. fumigatus during active growth [24-26]. This protein is a ribotoxin, which shares a high degree of sequence and structural homology with the dimeric $36 \mathrm{kDa}$ ribotoxin mitogillin from A. fumigatus [27], the $18 \mathrm{kDa}$ ribotoxin restrictocin from Aspergillus restrictus [28], the ribotoxin $\alpha$-sarcin from Aspergillus giganteus [29,30], and the ribotoxin c-sarcin (clavin) from Aspergillus clavatus [31]. Furthermore, it has been shown that the $18 \mathrm{kDa}$ ribotoxin is synonymous with the $A$. fumigatus ribotoxin Asp $f$ I [32,33], a major IgE-binding allergen implicated in ABPA, aspergilloma, and cystic fibrosis with complication of ABPA [34-39].

In this paper, we report the development of a murine $\operatorname{IgG} 1 \mathrm{mAb}, \mathrm{PD}{ }^{\circledR}$, raised against the $A$. fumigatus ribotoxin mitogillin, and which binds to an epitope conserved amongst the Aspergillus ribotoxins mitogillin, Asp $f \mathrm{I}$, restrictocin, and $\alpha$-sarcin. Using the $\mathrm{mAb}$, which is specific to A. fumigatus and clinically-relevant sibling species in the section Fumigati [40-42], we have developed a lateral-flow assay known as $A f u-\mathrm{LFD}^{\circledR}$ (Aspergillus fumigatus-Lateral Flow Device) and a sandwich ELISA $\left(A f u\right.$-ELISA $\left.{ }^{\circledR}\right)$ for the detection of the protein biomarker. Furthermore, using the $A f u$-LFD ${ }^{\circledR}$ immunoassay, we have developed a rapid and noninvasive urine-based test for IPA in humans caused by A. fumigatus.

\section{Materials and Methods}

\subsection{Ethics Statement}

Hybridoma work described in this study was conducted under a UK Home Office Project License, and was reviewed by the institution's Animal Welfare Ethical Review Board (AWERB) for approval. The work was carried out in accordance with The Animals (Scientific Procedures) Act 1986 Directive 2010/63/EU, and followed all the Codes of Practice which reinforce this law, including all elements of housing, care, and euthanasia of the animals. For collection of human urine samples, the study adhered to the Declaration 
of Helsinki, 2013, Good Clinical Practice, and was approved by the local ethics committee, Medical University of Graz, Austria (EC number 23-343).

\subsection{Preparation of Immunogen and Immunisation Regime}

For hybridoma production, mice were immunised with recombinant mitogillin (mitF; MyBioSource, MBS1189059). The immunogen comprising mitF diluted to $1 \mathrm{mg}$ protein $/ \mathrm{mL}$ buffer was stored at $-20^{\circ} \mathrm{C}$ before animal immunisations. For immunisations, 6 -wk-old $\mathrm{BALB} / \mathrm{c}$ white mice were each given four intra-peritoneal injections ( $300 \mu \mathrm{L}$ per injection) of immunogen at $2 \mathrm{wk}$ intervals, and a single booster injection was given five days before fusion.

\subsection{Production of Hybridomas and Screening by PTA-ELISA}

Hybridoma cells were produced by the method described elsewhere [43], and monoclonal antibody $(\mathrm{mAb})$-producing clones identified in Plate-Trapped Antigen EnzymeLinked Immunosorbent Assay (PTA-ELISA) tests, by using the immunogen diluted in phosphate-buffered saline (PBS; $137 \mathrm{mM} \mathrm{NaCl}, 2.7 \mathrm{mM} \mathrm{KCl}, 8 \mathrm{mM} \mathrm{Na}_{2} \mathrm{HPO}_{4}, 1.5 \mathrm{mM}$ $\mathrm{KH}_{2} \mathrm{PO}_{4}[\mathrm{pH}$ 7.2]) and immobilised to Maxisorp microtiter plate wells (Nunc) at $50 \mu \mathrm{L} /$ well. Wells containing immobilised antigen were incubated with $50 \mu \mathrm{L}$ of mAb hybridoma tissue culture supernatant (TCS) for $1 \mathrm{~h}$, after which wells were washed three times, for $5 \mathrm{~min}$ each, with PBST (PBS containing $0.05 \%$ (vol:vol) Tween-20). Goat anti-mouse polyvalent immunoglobulin (G, A, M) peroxidase conjugate (A0412, Sigma, St. Louis, MI, USA), diluted 1:1000 in PBST, was added to the wells and incubated for a further hour. The plates were washed with PBST as described, given a final 5 min wash with PBS, and bound antibody visualised by incubating wells with tetramethyl benzidine (TMB) substrate solution for $30 \mathrm{~min}$, after which reactions were stopped by the addition of $3 \mathrm{M} \mathrm{H}_{2} \mathrm{SO}_{4}$. Absorbance values were determined at $450 \mathrm{~nm}$ using a microplate reader (Tecan GENios, Tecan Austria $\mathrm{GmbH}$, Grödig, Austria). Control wells were incubated with tissue culture medium (TCM) containing 10\% (vol:vol) foetal bovine serum (FBS; FCS-SA, Labtech International Ltd., Heathfield, UK) only. All incubation steps were performed at $23^{\circ} \mathrm{C}$ in sealed plastic bags. The threshold for detection of the antigen in PTA-ELISA was determined from control means $(2 \times$ TCM absorbance values). These values were consistently in the range of $0.050-0.100$. Consequently, absorbance values $\geq 0.100$ were considered as positive for the detection of antigen.

\subsection{Determination of Ig Class and Sub-Cloning Procedure}

The Ig class of mAbs was determined by using PTA-ELISA. Wells of microtiter plates coated with immunogen were incubated successively with hybridoma TCS for $1 \mathrm{~h}$, followed by goat anti-mouse IgG1-, IgG2a-, IgG2b-, IgG3-, IgM- or IgA-specific antiserum (ISO-2, Sigma) diluted 1:3000 in PBST for $30 \mathrm{~min}$, and rabbit anti-goat peroxidase conjugate (A5420, Sigma) diluted 1:1000 for a further $30 \mathrm{~min}$. Bound antibody was visualised with TMB substrate as described. Hybridoma cell lines were sub-cloned three times by limiting dilution, and cell lines were grown in bulk in a non-selective medium, preserved by slowly freezing in FBS/dimethyl sulfoxide (92:8 vol:vol), and stored in liquid $\mathrm{N}_{2}$.

\subsection{Purification and Enzyme Conjugation of $m A$ ss}

Hybridoma TCS was harvested by centrifugation at $2147 \times g$ for $40 \mathrm{~min}$ at $4{ }^{\circ} \mathrm{C}$, followed by filtration through a $0.8 \mu \mathrm{M}$ cellulose acetate filter (10462240, Fisher Scientific, Loughborough, UK). Culture supernatant was loaded onto a HiTrap protein A column (17-0402-01, GE Healthcare Life Sciences) using a peristaltic pump P-1 (18-1110-91, GE Healthcare Life Sciences) with a low pulsation flow of $1 \mathrm{~mL} / \mathrm{min}$. Columns were equilibrated with $10 \mathrm{~mL}$ PBS, and column-bound antibody was eluted with $5 \mathrm{~mL}$ of $0.1 \mathrm{M}$ glycine- $\mathrm{HCl}$ buffer ( $\mathrm{pH} 2.5$ ) with a flow rate of $0.5 \mathrm{~mL} / \mathrm{min}$. The buffer of the purified antibody was exchanged to PBS using a disposable PD-10 desalting column (17-0851-01, GE Healthcare Life Sciences). Following purification, the antibody was sterile filtered with a $0.24 \mu \mathrm{m}$ syringe filter (85037-574-44, Fisher Scientific, Loughborough, UK) and stored at 
$4{ }^{\circ} \mathrm{C}$. Protein concentration was determined using a Nanodrop spectrophotometer with protein concentration calculated using the mass extinction coefficient of 13.7 at $280 \mathrm{~nm}$ for a $1 \%(10 \mathrm{mg} / \mathrm{mL}) \mathrm{IgG}$ solution. Antibody purity was confirmed by SDS-PAGE and gel staining using Coomassie Brilliant Blue R-250 dye (Thermo Fisher Scientific, Waltham, MA, USA). Protein A-purified mAb PD7 or mAb JF5 [12] was conjugated to horseradish peroxidase (PD7-HRP or JF5-HRP) for ELISA studies using a Lightning-Link horseradish peroxidase conjugation kit (701-0000; Bio-Techne Ltd., Abingdon, UK), or to alkaline phosphatase (PD7-AKP or JF5-AKP) for Western blotting studies using a Lightning-Link alkaline phosphatase conjugation kit (702-0010; Bio-Techne Ltd.).

\subsection{PD7 Recognition of Aspergillus Ribotoxins by SDS-PAGE and Western Blotting}

Recognition of different Aspergillus ribotoxins by mAb PD7 was determined by sodiumdodecyl-sulphate-polyacrylamide gel electrophoresis (SDS-PAGE) and Western blotting, using 4-20\% gradient polyacrylamide gels (4561094, Bio-Rad) under denaturing conditions. Proteins were separated electrophoretically at $165 \mathrm{~V}$, and pre-stained markers (1610377, Bio-Rad) were used for molecular weight determinations. For Western blotting, separated proteins were transferred electrophoretically onto a PVDF membrane (1620175, Bio-Rad) for $2 \mathrm{~h}$ at $75 \mathrm{~V}$, and the membrane was blocked for $16 \mathrm{~h}$ at $4{ }^{\circ} \mathrm{C}$ in PBS containing $1 \%$ (wt:vol) BSA. Blocked membranes were incubated with PD7-AKP conjugate diluted 1 in 5000 in PBS containing $0.5 \%$ (wt:vol) BSA (PBSA) for $2 \mathrm{~h}$ at $23{ }^{\circ} \mathrm{C}$. Membranes were washed three times with PBS, once with PBST, and bound antibody visualised by incubation in substrate solution [43]. Reactions were stopped by immersing membranes in $\mathrm{dH}_{2} \mathrm{O}$, and membranes were then air-dried between sheets of Whatman filter paper.

\subsection{Binding Kinetics of $m A b P D 7$ and Limits of Detection in PTA-ELISA}

Binding kinetics of mAb PD7 were measured using Bio-Layer Interferometry (BLI) technology from ForteBio (using the BLItz biosensor system, ForteBio, Pall). For all steps, sterile filtered PBS was used as running buffer, and solutions were agitated at $1000 \mathrm{RPM}$. Following an initial baseline of $30 \mathrm{~s}$, protein A-purified PD7, at a concentration of $50 \mu \mathrm{g} / \mathrm{mL}$, was immobilised on anti-mouse Fc capture biosensors (ForteBio, 18-5088) for $120 \mathrm{~s}$. After a second baseline step of $60 \mathrm{~s}$, bound PD7 was associated with recombinant mitF, between $69.44 \mathrm{nM}$ and $277.8 \mathrm{nM}$, for $60 \mathrm{~s}$. This was followed by dissociation in PBS for $120 \mathrm{~s}$. A reference, PD7-bound, biosensor with association and dissociation steps in PBS alone was used for background correction. ForteBio analysis software was used to fit binding curves to a global 1:1 binding model and to calculate kinetic constants.

\subsection{Heat Stability, Native PAGE and Western Blotting}

Heat stability of the PD7 epitope was determined by heating mitF and Asp $f$ I proteins in a boiling water bath. At 10 min intervals, $50 \mu \mathrm{L}$ volumes were removed and, after cooling, were transferred to the wells of microtitre wells for assay by ELISA using mAb PD7. For native PAGE, samples were heated for different time periods, diluted in native sample buffer (1610738, Bio-Rad), and then electrophoresed under non-denaturing conditions using 4-20\% gradient polyacrylamide gels (4561094, Bio-Rad), prior to Western blotting, and processing with $\mathrm{mAb}$ PD7, as described.

\subsection{Fungal Culture}

Fungi (Table 1) were routinely cultured on Malt Extract Agar (MEA; $20 \mathrm{~g}$ each of malt extract broth (MEB; LP0039, Thermo Fisher Scientific Oxoid Ltd., Basingstoke, UK and agar No. 2 (Neogen) in $1 \mathrm{~L}$ distilled water). The medium was autoclaved at $121^{\circ} \mathrm{C}$ for $15 \mathrm{~min}$ prior to use, and fungi were grown at $37^{\circ} \mathrm{C}$ under a $16 \mathrm{~h}$ fluorescent light regime. For recovery of $A$. fumigatus strains from naturally-infected soils, samples were sprinkled on the surface of MEA containing $50 \mathrm{mg} / \mathrm{L}$ chloramphenicol, and then incubated at $37^{\circ} \mathrm{C}$ for $48 \mathrm{~h}$. Putative isolates of $A$. fumigatus, identified by gross morphology and microscopy, were single-spore isolated and then grown in axenic culture on MEA. Polymerase chain reaction 
was then used to confirm identity using A. fumigatus-specific primers which amplify the Asp $f$ I-encoding gene [44].

Table 1. Details of fungi used in this study, and summary of $A f u$-ELISA ${ }^{\circledR}$ and $A f u$-LFD ${ }^{\circledR}$ specificities.

\begin{tabular}{|c|c|c|c|c|}
\hline Species & Isolate Number & Source $^{1}$ & $A f u$-ELISA ${ }^{\circledR}$ & $A f u$-LFD ${ }^{\circledR}$ \\
\hline Aspergillus flavus & 144B (KP794109) & CRT & - & - \\
\hline Aspergillus flavus & 91856 iii & IMI & - & - \\
\hline Aspergillus fumigatus & Af293 & SK & + & + \\
\hline Aspergillus fumigatus & $\Delta \mathrm{Af} m i t F:: h p h 2.1^{2}$ & This study & - & - \\
\hline Aspergillus fumigatus & $\Delta \mathrm{AfmitF}:: h p h 3.4^{2}$ & This study & - & - \\
\hline Aspergillus fumigatus & $\Delta \mathrm{AfbrlA7}^{3}$ & FGSC & + & + \\
\hline Aspergillus fumigatus & Af77 & CRT & + & + \\
\hline Aspergillus fumigatus & $\mathrm{CM}^{4}$ & CRT & + & + \\
\hline Aspergillus fumigatus & $\mathrm{GG}^{4}$ & CRT & + & + \\
\hline Aspergillus fumigatus & $\mathrm{SP}^{4}$ & CRT & + & + \\
\hline Aspergillus fumigatus & SX644764 & CRT & + & + \\
\hline Aspergillus fumigatus & SX705799 4 & CRT & + & + \\
\hline Aspergillus fumigatus & SX751776 ${ }^{4}$ & CRT & + & + \\
\hline Aspergillus fumigatus & SX757770 4 & CRT & + & + \\
\hline Aspergillus fumigatus & SX787789 4 & CRT & + & + \\
\hline Aspergillus fumigatus & SX705795 ${ }^{4}$ & CRT & + & + \\
\hline Aspergillus fumigatus & SX747754 ${ }^{4}$ & CRT & + & + \\
\hline Aspergillus fumigatus & SX746755 ${ }^{4}$ & CRT & + & + \\
\hline Aspergillus fumigatus & SX750763 ${ }^{4}$ & CRT & + & + \\
\hline Aspergillus fumigatus & SX750764 & CRT & + & + \\
\hline Aspergillus fumigatiaffinis & 117186 & CBS & + & + \\
\hline Aspergillus lentulus & 116882 & CBS & + & + \\
\hline Aspergillus nidulans & A4 & FGSC & - & - \\
\hline Aspergillus niger & 102.40 & CBS & - & - \\
\hline Aspergillus niger & $1 \mathrm{C}$ & CRT & - & - \\
\hline Aspergillus niger & B1 & CRT & - & - \\
\hline Aspergillus terreus var. terreus & 601.65 & CBS & - & - \\
\hline Aspergillus udugawae & 142231 & CBS & + & + \\
\hline Aspergillus viridinutans & 121595 & CBS & + & + \\
\hline Fusarium oxysporum & 167.30 & CBS & - & - \\
\hline Fusarium solani & 224.34 & CBS & - & - \\
\hline Lomentospora prolificans & 3.1 & CRT & - & - \\
\hline Neosartorya fischeri & 544.65 & CBS & + & + \\
\hline Neosartorya pseudofischeri & 100504 & CBS & + & + \\
\hline Lichtheimia corymbifera & T14A (FJ713070) & CRT & - & - \\
\hline
\end{tabular}


Table 1. Cont.

\begin{tabular}{|c|c|c|c|c|}
\hline Species & Isolate Number & Source $^{1}$ & $A f u$-ELISA ${ }^{\circledR}$ & $A f u$-LFD ${ }^{\circledR}$ \\
\hline Rhizopus oryzae & 111233 & CBS & - & - \\
\hline Scedosporium apiospermum & 117467 & CBS & - & - \\
\hline Scedosporium aurantiacum & 121926 & CBS & - & - \\
\hline
\end{tabular}

${ }^{1}$ CBS: Westerdijk Fungal Biodiversity Institute, The Netherlands. SK: S. Krappman, Institute of Clinical Microbiology, Immunology and Hygiene, Universitätsklinikum Erlangen and Freidrich-Alexander-Universität, Germany. FGSC: Fungal Genetics Stock Centre, Kansas City University, USA. CRT: C.R. Thornton, University of Exeter, UK. ${ }^{2}$ Mitogillin-deficient mutants of $A$. fumigatus Af293 generated in this study. ${ }^{3}$ Non-sporulating mutant of $A$. fumigatus Af293 [45,46]. ${ }^{4}$ Strains recovered in this study from naturally-infested soil samples; SX denotes the grid references of peat samples from Dartmoor National Park from which strains were isolated. For Afu-ELISA ${ }^{\circledR}$ $(+)$ indicates positive test result, with mean absorbance value greater than the threshold value for test positivity $(\geq 0.100) ;(-)$ indicates negative test result, with mean absorbance value less than the threshold value for test positivity. For $A f u$-LFD ${ }^{\circledR},(+)$ indicates positive test result with protein precipitate [both control $(\mathrm{C})$ and test $(\mathrm{T})$ lines visible]; (-) indicates negative test result with protein precipitate [control (C) line visible only]

\subsection{Generation of A. fumigatus Ribotoxin-Deficient Mutants}

Targeted gene replacement of the A. fumigatus mitogillin-encoding gene (mitF) with the hygromycin B phosphotransferase-encoding gene $(h p h)$ was performed using the split marker recombination strategy as described previously $[13,47,48]$. The mitF gene and flanking sequences were obtained from the Aspergillus Genome Database (AspGD, http:/ /www.aspergillusgenome.org/), and used to design primers accordingly (Table S1). Primer pairs mitF_LF.1_F/mitF_LF.1_R and mitF_RF.1_F/mitF_RF.1_R were used to amplify the $5^{\prime}(\mathrm{LF}, 0.8 \mathrm{~kb})$ and $3^{\prime}(\mathrm{RF}, 1.0 \mathrm{~kb})$ flanking regions of the mitF gene, respectively, from A. fumigatus Af293 genomic DNA. Simultaneously, split $h p h$ templates were amplified to create the $5^{\prime}$ amplicon (HY, $1.2 \mathrm{~kb}$ ) using primers $\mathrm{HY}$ split/M13F, and $3^{\prime}$ amplicon (YG, $0.8 \mathrm{~kb}$ ) using primers YG split/M13R. Fusion PCR resulted in two products, LFHY $(2.0 \mathrm{~kb})$ and RFYG $(1.8 \mathrm{~kb})$ using primer pairs mitF_LF.1_F/HY split and mitF_RF.1_R/YG split, respectively. The amplicons were gel purified and used in Af293 protoplast transformation giving way to replacement of mit $F$ with the successfully assembled $h p h$ gene, conferring hygromycin $\mathrm{B}$ resistance. Putative $\triangle \mathrm{AfmitF}:: h p h$ transformants were selected in the presence of hygromycin $B(600 \mu \mathrm{g} / \mathrm{mL})$ and gene replacement was confirmed by size difference PCR. PCR products were amplified from genomic DNA using the primer pair mitF_LF.1_F/mitF_RF.1_R. The products therefore contained both the LF $(0.8 \mathrm{~kb})$ and RF $(1.0 \mathrm{~kb})$ flanking regions of the mitF gene, with either the mitF $(0.5 \mathrm{~kb})$ or assembled $h p h$ gene $(1.6 \mathrm{~kb})$, with predicted sizes of $2.5 \mathrm{~kb}$ for the wild-type strain Af2 293 or $3.6 \mathrm{~kb}$ for gene replacement mutants.

\subsection{Production of Ribotoxins In Vitro}

For ribotoxin production studies, Aspergillus species were grown in liquid Aspergillus Minimal Medium (AMM) [49]. Unrelated species were grown in MEB, but were otherwise treated similarly. Three replicate $250 \mathrm{~mL}$ conical flasks containing $100 \mathrm{~mL}$ of autoclaved medium were inoculated with spores to a final concentration of $10^{3}$ spores $/ \mathrm{mL}$, and the cultures incubated at $37^{\circ} \mathrm{C}$ with shaking (120 RPM) in a New Brunswick orbital shaker. For the A. fumigatus sporulation-deficient mutant $\triangle \mathrm{Af} b r l A$, the flasks were inoculated with $3 \mathrm{~mm} \times 5 \mathrm{~mm}$ plugs of mycelium taken from the leading edge of a culture grown for $48 \mathrm{~h}$ at $37^{\circ} \mathrm{C}$ on MEB. At $24 \mathrm{~h}$ intervals, replicate flasks were harvested and culture fluids separated from mycelium by filtration through Miracloth. Mycelial biomass was dried for $4 \mathrm{~d}$ at $80^{\circ} \mathrm{C}$ and weighed. Culture filtrates were mixed with ethanol at a ratio of 1:4 (vol:vol) and chilled at $-20^{\circ} \mathrm{C}$ for $16 \mathrm{~h}$ to allow protein precipitation. After centrifugation at $4{ }^{\circ} \mathrm{C}$ for $10 \mathrm{~min}$ at $3202 \times \mathrm{g}$, protein pellets were washed once with chilled ethanol, and centrifuged for a further $5 \mathrm{~min}$. The clear supernatants were aspirated, the pellets air-dried, re-suspended in PBS, and protein suspensions stored at $-80^{\circ} \mathrm{C}$. On thawing, any insoluble material was removed by centrifugation for $5 \mathrm{~min}$ at $16,000 \times \mathrm{g}$, and solutions heated for 
10 min in a boiling water bath prior to immunoassay by $A f u$-ELISA ${ }^{\circledR}$, or SDS-PAGE and Western blotting. The heating step was not required for assay by PTA-ELISA.

For colony blots, A. fumigatus Af293 and the ribotoxin-deficient $\triangle$ AfmitF::hph mutants were grown for $48 \mathrm{~h}$ at $37^{\circ} \mathrm{C}$ on MEB, after which time the colonies were overlayed with PVDF membrane for $8 \mathrm{~h}$. The membranes were blocked and processed with PD7-AKP or JF5-AKP conjugates as described for Western blotting.

\subsection{Afu-ELISA ${ }^{\circledR}$}

Wells of Maxisorp microtiter plate wells (Nunc) were coated for $16 \mathrm{~h}$ at $4{ }^{\circ} \mathrm{C}$ with $50 \mu \mathrm{L}$ volumes of protein A-purified mAb PD7 at a concentration of $1 \mu \mathrm{g} / \mathrm{mL}$ in PBS. The wells were incubated with heat-treated protein solutions for $2 \mathrm{~h}$, washed three times $(5 \mathrm{~min}$ each) with PBST, and then incubated for $1 \mathrm{~h}$ with PD7-HRP conjugate diluted 1 in 1000 in PBST (equivalent to $\sim 1 \mu \mathrm{g}$ antibody protein $/ \mathrm{mL}$ buffer). The wells were washed with PBST as described, given a final 5 min wash with PBS, and bound antibody visualised by incubating wells with tetramethyl benzidine (TMB) substrate solution for $30 \mathrm{~min}$, after which reactions were stopped by the addition of $3 \mathrm{M} \mathrm{H}_{2} \mathrm{SO}_{4}$. Absorbance values were determined at $450 \mathrm{~nm}$ using a microplate reader (Tecan GENios, Tecan Austria GmbH). All incubation steps were performed at $23^{\circ} \mathrm{C}$ in sealed plastic bags. The threshold for detection of the PD7 antigen in Afu-ELISA ${ }^{\circledR}$ was determined from the means of controls (AMM or MEB only). These values were consistently in the range of $0.050-0.100$. Consequently, absorbance values $\geq 0.100$ were considered as positive for the detection of antigen. The limit of detection of the $A f u$-ELISA ${ }^{\circledR}$ was determined from a calibration curve of known concentrations of heat-treated Asp $f$ I diluted in PBST.

\subsection{Detection of Asp f I in Urine}

2.13.1. Configuration of the Lateral-Flow Device

The lateral-flow assay, known as $A f u$-LFD ${ }^{\circledR}$, was manufactured by Lateral Dx (Alloa, Scotland, UK). The test consisted of Kenosha $75 \mathrm{~mm}$ backing card; Ahlstrom 222 and 1281 top and sample pads, respectively; and a Sartorius CN95 nitrocellulose membrane. Monoclonal antibody PD7 was conjugated to NanoAct ${ }^{\circledR}$ Red CNB particles (Asahi Kasei) according to the manufacturer's instructions, and applied to the release pad. The test line antibody consisted of $\mathrm{mAb}$ PD7 at $1 \mathrm{mg}$ protein $/ \mathrm{mL}$, while a commercial goat anti-mouse IgG (BBI Solutions) acted as the control line.

\subsubsection{Limit of Detection of the Afu-LFD ${ }^{\circledR}$ Test}

The limit of detection (LOD) of the $A f u-\mathrm{LFD}^{\circledR}$ test was determined using first void urine (FVU) samples from three independent healthy donors. Five hundred $\mu \mathrm{L}$ volumes of urine spiked with known concentrations of recombinant Asp $f$ I were added to Amicon Ultra-0.5 centrifugal (10 kDa cut-off) filter units (Sigma, UFC5010BK), and concentrated 10 -fold by centrifugation for 5 min at $14,000 \times g$, followed by buffer exchange with $400 \mu \mathrm{L}$ PBS for $8 \mathrm{~min}$ at $14,000 \times \mathrm{g}$. Concentrated samples were recovered by centrifugation at $1000 \times g$ for $2 \mathrm{~min}$, and then heated for $10 \mathrm{~min}$ in a boiling water bath. Cooled samples were then mixed 1:1 (vol:vol) with $2 \times$ PBS containing $0.2 \%$ (vol:vol) Tween-20, and the resultant $100 \mu \mathrm{L}$ volumes then added to $A f u$-LFD ${ }^{\circledR}$ devices. The negative control consisted of un-spiked FVU, which was otherwise processed according to spiked samples. Test results were recorded after $30 \mathrm{~min}$ as negative [single internal control (C) line only] or positive [both control $(\mathrm{C})$ and test $(\mathrm{T})$ lines visible] for the PD7 protein biomarker.

\subsection{Processing and Testing of Patient Urine Samples Using the Afu-LFD ${ }^{\circledR}$ Test}

Patient urine samples stored at $-80{ }^{\circ} \mathrm{C}$ were thawed, vortexed briefly, and then centrifuged for $10 \mathrm{~min}$ at $16,000 \times \mathrm{g}$. Five hundred $\mu \mathrm{L}$ of urine supernatant was added to an Amicon Ultra-0.5 centrifugal (10 kDa cut-off) filter unit (Sigma, UFC5010BK), and concentrated 10-fold by centrifugation for $5 \mathrm{~min}$ at $14,000 \times g$, followed by buffer exchange with $400 \mu \mathrm{L}$ PBS for $8 \mathrm{~min}$ at $14,000 \times g$. The concentrated sample was recovered by 
centrifugation at $1000 \times g$ for $2 \mathrm{~min}$, and then heated for $10 \mathrm{~min}$ in a boiling water bath. For $A f u$-LFD ${ }^{\circledR}$ tests, the cooled sample was mixed 1:1 (vol:vol) with $2 \times$ PBS containing $0.2 \%$ (vol:vol) Tween-20, and the resultant $100 \mu \mathrm{L}$ volume then added to an $A f u$-LFD ${ }^{\circledR}$ device. Test results were recorded after $30 \mathrm{~min}$ as negative [single internal control (C) line only] or positive [both control (C) and test $(\mathrm{T})$ lines visible] for the PD7 protein biomarker.

\subsection{SDS-PAGE, Western Blotting, and LC-MS of Patient Urine Sample}

For SDS-PAGE and Western blotting, concentrated and buffered-exchanged urine samples were mixed with Laemmli buffer, and processed with mAb PD7 as described previously. Immuno-reactive bands were located on replica SDS-PAGE gels stained with Coomassie Blue, removed with a scalpel blade and digested with trypsin using a ProGest automated digestion unit (Perkin Elmer Life Sciences (UK) Ltd., Beaconsfield, UK). The resulting peptides were analysed by mass spectrometry using a 4700 MALDI-TofTof mass spectrometer (Applied Biosystems, Foster City, CA, USA) to give a peptide mass fingerprint and peptide sequence information, which was searched against various databases using the Mascot search programme (www.matrixscience.com) to identify the protein present in the gel band.

\subsection{Statistical Analysis}

All statistical analyses were performed using RStudio software with the Agricolae extension package. ANOVA was conducted with null hypothesis. Where $p<0.05$, the null hypothesis was rejected and a post-hoc Tukey test was conducted.

\section{Results}

\subsection{Production of Hybridomas and $m A b$ Isotyping}

Two hybridoma fusions were performed, and 855 hybridoma cell lines were tested in PTA-ELISA for recognition of the immunogen. Thirty-six cell lines produced immunoreactive antibodies, with 21 producing $\mathrm{mAbs}$ of the immunoglobulin class $\mathrm{G}$. The cell line PD7 was selected for further testing based on the strength of its reaction with the immunogen in ELISA, and its ability to recognize native protein produced by A. fumigatus Af293. Isotyping of $\mathrm{mAb}$ PD7 showed that it belonged to immunoglobulin class G1 (IgG1).

\subsection{Recognition of Aspergillus Ribotoxins by $m A b$ PD7}

In SDS-PAGE and Western blotting studies, mAb PD7 bound to all six of the Aspergillus ribotoxins tested (Figure 1). Binding of PD7 to the immunogen (recombinant mitogillin) is in keeping with the estimated molecular weight for this protein dimer $(\sim 36 \mathrm{kDa})$. Native restrictocin, and protein precipitate prepared from 72-h-old AMM culture filtrate of $A$. fumigatus Af293 (this study), yielded PD7-reactive bands of $\sim 18 \mathrm{kDa}$, consistent with the monomeric Asp $f$ I ribotoxin produced by the pathogen. A recombinant form of this Asp $f$ I ribotoxin gave a major PD7-reactive band of $\sim 19 \mathrm{kDa}$, comprising the $18 \mathrm{kDa}$ protein and an additional $1 \mathrm{kDa}$ from a 6xHis-tag. Major PD7-reactive bands of $\sim 30 \mathrm{kDa}$ were present in the recombinant restrictocin and $\alpha$-sarcin preparations, in addition to immunoreactive bands with higher ( $\sim 50 \mathrm{kDa}$, both preparations) and lower $(\sim 19 \mathrm{kDa}$, recombinant restrictocin only) molecular weights. 


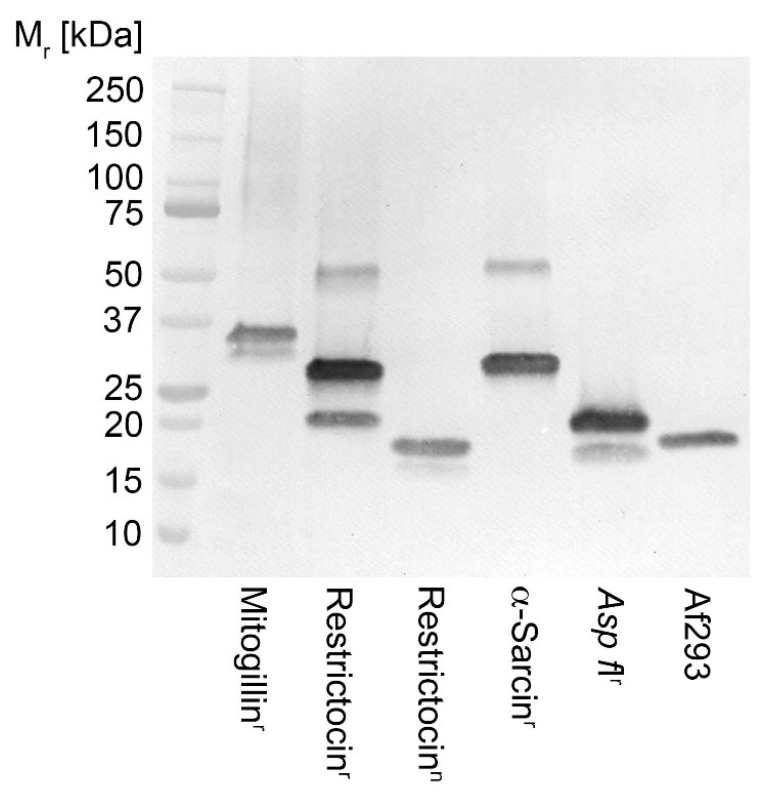

Figure 1. Western immunoblot of different Aspergillus ribotoxins using $\mathrm{mAb}$ PD7. Mitogillin ${ }^{\mathrm{r}}=$ recombinant mitogillin (mitF) from Aspergillus fumigatus (MBS1189059); Restrictocin ${ }^{\mathrm{r}}=$ recombinant restrictocin from Aspergillus restrictus (MBS1228220); Restrictocin ${ }^{\mathrm{n}}=$ native restrictocin from Aspergillus restrictus (Sigma R0381); $\alpha$-Sarcin ${ }^{\mathrm{r}}=$ recombinant $\alpha$-sarcin from Aspergillus giganteus (MBS1239731); Aspf $\mathrm{I}^{\mathrm{r}}=$ recombinant Asp $f$ I from A. fumigatus (RP-AF1-1); Af293 = protein precipitate from 72-h-old AMM culture filtrate of Aspergillus fumigatus Af293 (this study). Each well contains $40 \mathrm{ng}$ of protein.

\subsection{Binding Kinetics of $m A b P D 7$ and Limits of Detection of PTA-ELISA and Afu-ELISA ${ }^{\circledR}$}

The equilibrium dissociation constant $\left(\mathrm{K}_{\mathrm{D}}\right)$ of $\mathrm{mAb}$ PD7 determined by Bio-Layer Interferometry (Figure S1A) using the dimer mitF was $1.02 \times 10^{-7}$ (Table S2), showing that $\mathrm{mAb}$ PD7 has $\mathrm{nM}$ sensitivity. The limit of antigen detection in the PTA-ELISA was determined as $4 \mathrm{ng} / \mathrm{mL}$ for both the dimer mitF and for the monomer Asp $f$ I (Figure S1B), while the limit of detection of the $A f u$-ELISA ${ }^{\circledR}$ was determined as $\sim 15 \mathrm{ng} A s p f \mathrm{I} / \mathrm{mL}$ (Figure S1C).

\subsection{Heat Stability of the PD7 Epitope and Protein Aggregation}

The epitope bound by $\mathrm{mAb}$ PD7 is heat stable, with no significant effect on $\mathrm{mAb}$ binding following $60 \mathrm{~min}$ heating of the $36 \mathrm{kDa}$ dimer mitogillin (Figure S2A). Binding of PD7 to the monomeric protein Asp $f$ I was unaffected by heat treatment for up to $30 \mathrm{~min}$, but there was a significant progressive reduction in $\mathrm{mAb}$ binding thereafter (Figure S2A). Under native conditions, heating of Asp $f$ I led to progressive increases in PD7 binding in Western blots over time (Figure S2B).

\subsection{Production of Ribotoxins In Vitro}

A. fumigatus Af293 and Ribotoxin-Deficient Mutants

Hyphal growth of A. fumigatus Af293 in AMM shake culture peaked at $96 \mathrm{~h}$ postinoculation with a mean dry weight of $0.384 \mathrm{~g} \pm 0.037 \mathrm{~g}$ (Figure 2A), and coincided with sporulation by the fungus. Ribotoxin production, determined by both $A f u$-ELISA ${ }^{\circledR}$ (Figure 2B) and PTA-ELISA (Figure 2C) using mAb PD7, followed a similar trend, with ribotoxin production first detected $48 \mathrm{~h}$ post-inoculation (absorbance values of $\geq 0.100$, the threshold value for antigen positivity in both immunoassays), maximum ribotoxin production detected between $72 \mathrm{~h}$ and $96 \mathrm{~h}$ post-inoculation, and with a rapid decline after $96 \mathrm{~h}$ coincident with the cessation of hyphal growth and onset of sporulation. Western blot analysis (Figure 2D) using representative samples at each time point, revealed a similar trend to ELISA tests, with production of a single $18 \mathrm{kDa}$ ribotoxin first discernible 
at $48 \mathrm{~h}$ post-inoculation, stronger detection at both $72 \mathrm{~h}$ and $96 \mathrm{~h}$ post-inoculation, and absence of production thereafter. As a means of comparison with other extracellular Aspergillus antigens, we tested the same samples by PTA-ELISA (Figure 2E) and Western blot (Figure 2F) with mAb JF5, an Aspergillus-specific mAb that binds to galactofuranoserich peptidoglycans. The dynamics of JF5 antigen production were markedly different to those of ribotoxin production, with antigen production peaking at $48 \mathrm{~h}$ post-inoculation and plateauing thereafter. This shows that while both antigens are secreted into the culture filtrate in the early phases of fungal growth, and both require germination of spores for antigen production, ribotoxin production is strictly limited to the hyphal growth phase, and does not accumulate post-sporulation, unlike secreted peptidoglycans.

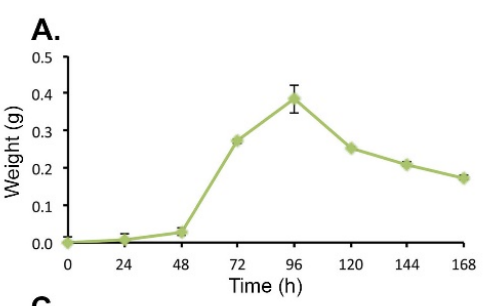

C.

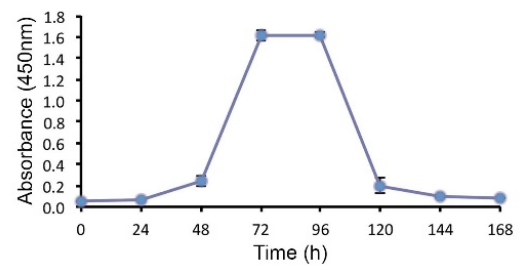

E.

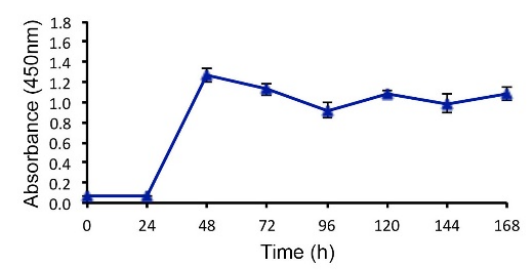

B.

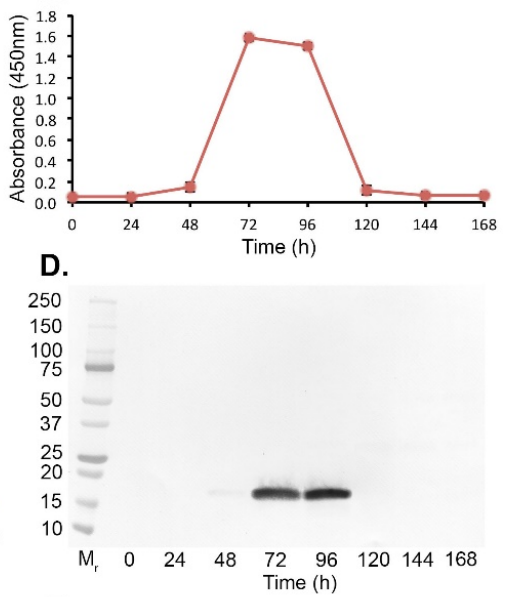

F.

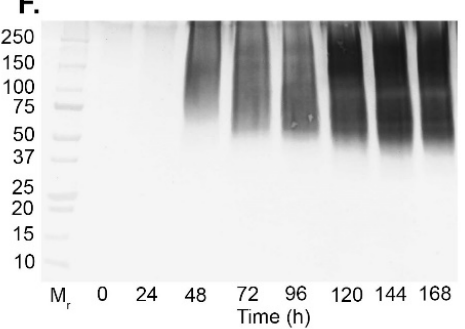

Figure 2. Production of the $18 \mathrm{kDa}$ ribotoxin by A. fumigatus Af293 in vitro. (A) Dry weights of the pathogen over the 7 day experimental period. (B) $A f u$-ELISA ${ }^{\circledR}$ of AMM protein precipitates, with the same samples tested by PTA-ELISA (C), using mAb PD7. Each data point in figures (A) to (C) is the mean of three replicates $\pm S E$, and the threshold absorbance value for detection of protein in the $A f u$-ELISA ${ }^{\circledR}$ is $\geq 0.100$. (D) Western blot of pooled replicate AMM protein precipitates using $\mathrm{mAb}$ PD7, showing weak detection of an $18 \mathrm{kDa}$ immuno-reactive band at $48 \mathrm{~h}$ post-inoculation, strong detection at $72 \mathrm{~h}$ and $96 \mathrm{~h}$ post-inoculation, and no detection thereafter. (E) PTA-ELISA detection of galactofuranose-rich peptidoglycans in protein precipitates using mAb JF5. Each data point is the mean absorbance value of three replicates \pm SE, and the threshold absorbance value for detection of glycoprotein in PTA-ELISA is $\geq 0.100$. (F) Western blot of pooled AMM protein precipitates using mAb JF5.

Mutants of $A$. fumigatus generated by targeted deletion of the ribotoxin-encoding gene mitF (Figure S3A) were deficient in ribotoxin production, but otherwise retained similar phenotypic characteristics (biomass accumulation in liquid culture) to those of the wild-type strain Af293 (Figure S3B). Protein precipitates from AMM cultures of two independent mutant strains ( $\triangle \mathrm{AfmitF}:$ hph2.1 and $\Delta \mathrm{AfmitF}:$ hph3.4) both failed to react with $\mathrm{mAb}$ PD7 in Western blotting (Figure S3C) tests, whereas they retained activity in Western blots with mAb JF5 (Figure S3D). Colony blots of these strains (Figure S3E) showed reaction of $\mathrm{mAb}$ PD7 with the leading edge of Af 293 colonies, but lack of reactivity with the 
mutant strains. As positive controls, blots probed with mAb JF5 showed intense staining of galactofuranose-rich peptidoglycans secreted by the leading edges of both the wild-type and mutant strains (Figure S3E).

\subsection{Ribotoxin Production by the A. fumigatus Sporulation-Deficient Mutant $\triangle A f b r l A$}

Hyphal growth of the sporulation-deficient mutant $\triangle \mathrm{Af} b r l A$ in AMM shake culture increased steadily over time and started to plateau at $168 \mathrm{~h}$ post-inoculation (Figure 3A). Ribotoxin production, determined by $A f u$-ELISA ${ }^{\circledR}$ using mAb PD7 (Figure 3B), was first detected $72 \mathrm{~h}$ post-inoculation, with production increasing steadily thereafter until $144 \mathrm{~h}$. Production then decreased concomitant with the plateauing in biomass accumulation. Western blot analysis (Figure 3C) using representative samples at each time point, revealed a similar trend to the $A f u$-ELISA ${ }^{\circledR}$ test, with production of a single $18 \mathrm{kDa}$ ribotoxin first discernible at $72 \mathrm{~h}$ post-inoculation, and with detection at all time points thereafter.

A.

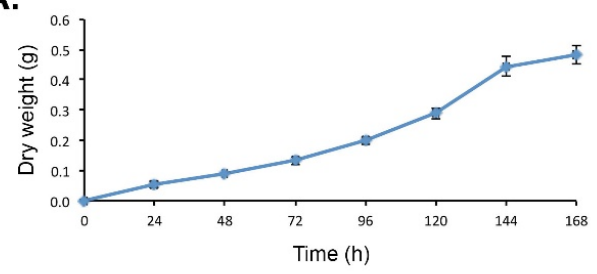

B.

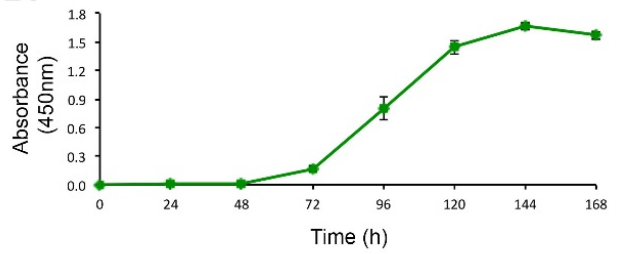

c.

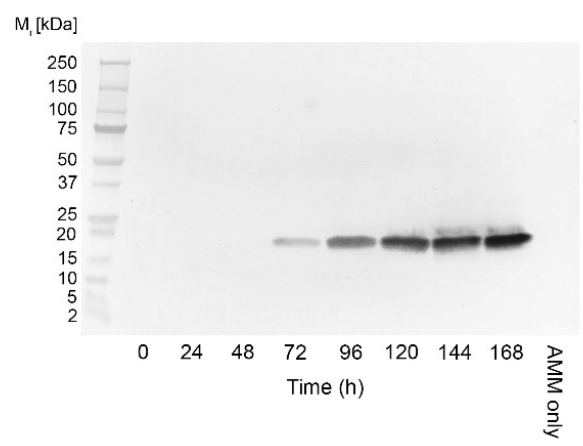

Figure 3. Production of the $18 \mathrm{kDa}$ ribotoxin by the $A$. fumigatus sporulation-deficient mutant $\triangle \mathrm{Af} b r \mathrm{~A}$ in vitro. (A) Dry weights of the mutant over the 7 day experimental period. (B) Afu-ELISA ${ }^{\circledR}$ of AMM protein precipitates using $\mathrm{mAb}$ PD7. Each data point in figures $(\mathbf{A}, \mathbf{B})$ is the mean of three replicates $\pm \mathrm{SE}$, and the threshold absorbance value for detection of protein in the $A f u$-ELISA ${ }^{\circledR}$ (B) is $\geq 0.100$. (C) Western blot of pooled protein samples, showing the appearance of the PD7-reactive $18 \mathrm{kDa}$ protein at $72 \mathrm{~h}$ post-inoculation and at each time point thereafter. The negative control comprised AMM only.

3.7. Production of Ribotoxins by Other Aspergillus Fumigatus Strains, Non-Fumigatus Aspergillus Species, and Unrelated Human Pathogenic Fungi

In order to determine whether mAb PD7 was reactive with ribotoxins produced by $A$. fumigatus strains other than isolate Af293, we tested an additional 14 independent isolates of the pathogen recovered from naturally-infested soil samples (Figure 4). We had first established, using ELISA and Western blotting tests of AMM protein precipitates of Af293 (Figure 2), that peak ribotoxin production occurred between $72 \mathrm{~h}$ and $96 \mathrm{~h}$ post-inoculation. 
We therefore grew the 14 different isolates (and Af293 as the positive control) in AMM for $72 \mathrm{~h}$, and tested their protein precipitates in the $A f u$-ELISA ${ }^{\circledR}$ and in Western blots using $\mathrm{mAb}$ PD7. There were no significant differences in the dry weights of all 15 isolates after $72 \mathrm{~h}$ growth in AMM (Figure 4A) and, while detection of the antigen in the ELISA (Figure 4B) was significantly less in a single strain (SX750763) compared to Af293, the absorbance value for this strain was greater than the threshold value for test positivity $(\geq 0.100)$. Western blots (Figure 4C,D) showed recognition by mAb PD7 of a single immunoreactive $18 \mathrm{kDa}$ antigen in all 15 isolates, while in the negative control (AMM only) the band was absent (Figure 4C).

A.

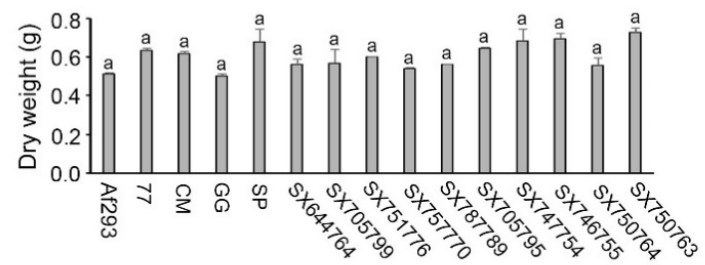

B.
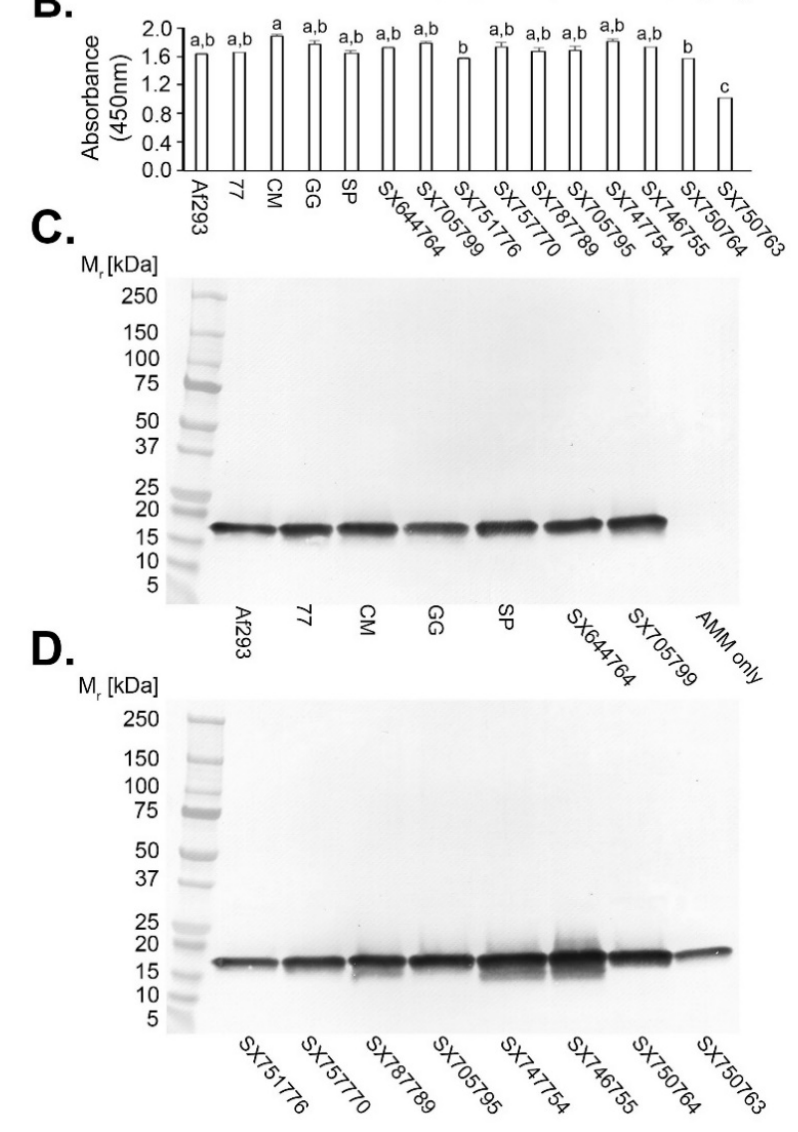

Figure 4. Production of the PD7-reactive $18 \mathrm{kDa}$ ribotoxin by different strains of A. fumigatus. All 14 strains were isolated from naturally-infested soils, and protein precipitates were prepared from 72-h-old AMM shake cultures. A. fumigatus Af293 acted as the positive control, while AMM only acted as the negative control. (A) Dry weights of strains after $72 \mathrm{~h}$ growth, showing no significant differences in weights compared to Af293. (B) While the mean absorbance value for strain SX750763 was significantly reduced in the $A f u$-ELISA ${ }^{\circledR}$, an $18 \mathrm{kDa}$ PD7-reactive band was present in all protein precipitates $(\mathbf{C}, \mathbf{D})$, with the exception of the negative control. Bars in $(\mathbf{A}, \mathbf{B})$ are the means of three replicate values $\pm \mathrm{SE}$, and bars with the same letter are not significantly different at $p<0.05$. The threshold absorbance value for detection of ribotoxin protein in the $A f u$-ELISA ${ }^{\circledR}$ (B) is $\geq 0.100$. 
We similarly tested other species of Aspergillus known to cause invasive pulmonary aspergillosis in humans, namely Aspergillus niger, A. flavus, A. nidulans, and A. terreus (Figure S4), and sibling species in the Aspergillus section Fumigati that have also been reported to cause the disease in humans [40], namely Aspergillus fumigatiaffinis, A. lentulus, A. udugawae, A. viridinutans, Neosartorya fischeri, and N. pseudofischeri (Aspergillus thermomutatus) (Figure S5). While the PD7-reactive $18 \mathrm{kDa}$ protein was absent in A. niger, A. flavus, $A$. nidulans, and $A$. terreus in both $A f u$-ELISA ${ }^{\circledR}$ and Western blotting tests (Figure S4B,C), consistent with the absence of ribotoxins in these species [32], $18 \mathrm{kDa}$ proteins were evident in the culture filtrates of the sibling species, and the positive control A. fumigatus Af293 (Figure S5). As with the other species, we initially tested 72-h-old AMM protein precipitates from the sibling species, which showed single PD7-reactive $18 \mathrm{kDa}$ proteins in culture filtrates of A. lentulus, N. pseudofischeri, A. viridinutans, and N. fischeri. No PD7-reactive protein was detected in 72-h-old protein precipitates of $A$. udugawae either in Afu-ELISA ${ }^{\circledR}$ or Western blotting tests (Figure S5B,C), while protein precipitates of A. fumigatiaffinis were positive in the sandwich $A f u$-ELISA ${ }^{\circledR}$ (Figure S5B), and produced two immuno-reactive bands in Western blots, one with a molecular weight of $18 \mathrm{kDa}$, and a further putative dimer of $\sim 36 \mathrm{kDa}$ (Figure S5C).

To further examine ribotoxin production in these two species, we extended the time period of their culture from 72 to $144 \mathrm{~h}$ (Figure S6). Using this extended sampling period, PD7-reactive $18 \mathrm{kDa}$ proteins were detectable in AMM culture filtrates of both species in both the Afu-ELISA ${ }^{\circledR}$ (Figure S6B), and in Western blotting tests (Figure S6D,E). The production of the higher molecular weight protein was again evident in 96-h-old culture filtrates of A. fumigatiaffinis (Figure S6E), consistent with the production of a dimer by this species [50].

Afu-ELISA ${ }^{\circledR}$ and Western blotting studies of protein precipitates from 72-h-old MEB culture filtrates from Fusarium solani and Fusarium oxysporum (causes of human fusariosis), Rhizopus oryzae and Lichtheimia corymbifera (causes of human mucormycosis), Scedosporium aurantiacum and Scedosporium apiospermum (causes of human scedosporiosis), and Lomentospora prolificans (the cause of lomentosporiosis) showed the absence of PD7-reactive proteins in these unrelated, but clinically relevant, human pathogenic moulds (Figure S7).

\subsection{Limit of Detection of the Afu-LFD ${ }^{\circledR}$ Test and Detection of Asp $f$ I in Patient Urine}

The limit of detection (LOD) of the $A f u$-LFD ${ }^{\circledR}$ test using FVU samples from healthy donors spiked with the $18 \mathrm{kDa}$ ribotoxin Asp $f$ I was $\sim 15 \mathrm{ng}$ protein/mL urine (Figure 5A). Faint test lines were visible using samples containing $15.6 \mathrm{ng}$ protein $/ \mathrm{mL}$ and $7.8 \mathrm{ng}$ protein $/ \mathrm{mL}$, but no test line was visible in negative control urine (un-spiked FVU). Urine from a patient with acute myeloid leukaemia diagnosed with probable IPA according to EORTC guidelines (with microbiological criteria consisting of a serum GM ODI of 3.36 and serum $\beta$-D-glucan of $52 \mathrm{pg} / \mathrm{mL}$, followed by a serum GM ODI of 1.84 four days later), yielded a weak but positive $A f u-L F D^{\circledR}$ test result (Figure $5 \mathrm{~B}$ ). Examination of this sample by Western blotting revealed two PD7-reactive bands with molecular weights of $\sim 19 \mathrm{kDa}$ and $\sim 12.5 \mathrm{kDa}$ (labelled 1 and 2, respectively, in Figure 5C). The corresponding proteins resolved in a replica SDS-PAGE gel stained with Coomassie Blue (Figure 5D) were subjected to LC/MS, which identified the $\sim 19 \mathrm{kDa}$ protein as A. fumigatus mitogillin (Figure 5E). The identity of the $12.5 \mathrm{kDa}$ PD7-reactive protein could not be established using this approach. 
A.

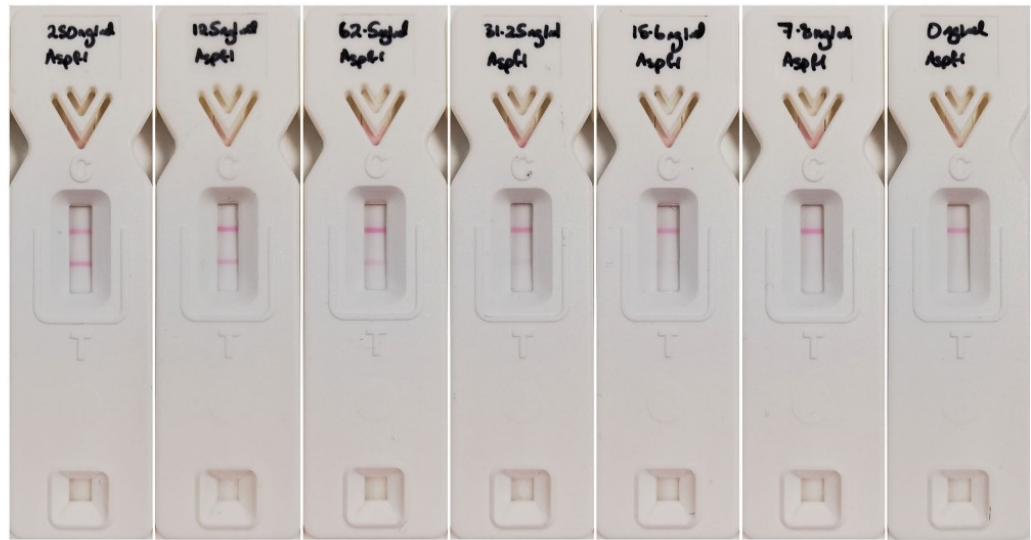

B.

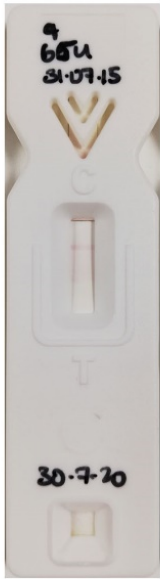

E.

\begin{tabular}{|l|l|l|l|l|l|l|l|l|l|l|}
\hline Accession & Description & Score & Coverage & $\begin{array}{l}\# \\
\text { Proteins }\end{array}$ & $\begin{array}{l}\text { \# Unique } \\
\text { Peptides }\end{array}$ & $\begin{array}{l}\# \\
\text { Peptides }\end{array}$ & $\begin{array}{l}\# \\
\text { PSMs }\end{array}$ & $\begin{array}{l}\# \\
\text { AAs }\end{array}$ & $\begin{array}{l}\text { MW } \\
\text { [kDa] }\end{array}$ & $\begin{array}{l}\text { Calc. } \\
\text { pl }\end{array}$ \\
\hline P67875 & $\begin{array}{l}\text { A. fumigatus } \\
\text { mitogillin }\end{array}$ & 312.15 & 46.02 & 1 & 7 & 7 & 15 & 176 & 19.6 & 9.13 \\
\hline
\end{tabular}

Figure 5. $A f u$-LFD ${ }^{\circledR}$ test results and identification of PD7 immuno-reactive proteins in patient urine sample (A). Representative $A f u$-LFD ${ }^{\circledR}$ test results using first volume urine (FVU) from a healthy donor spiked with known concentrations of A. fumigatus Asp $f$ I protein. Test results were recorded after $30 \mathrm{~min}$ as negative [single internal control (C) line only] or positive [both control $(\mathrm{C})$ and test $(\mathrm{T})$ lines visible] for the PD7 protein biomarker. Strong test lines are visible between $250 \mathrm{ng} / \mathrm{mL}$ and $31.25 \mathrm{ng} / \mathrm{mL}$, with faint test lines discernible in samples containing $15.6 \mathrm{ng}$ protein $/ \mathrm{mL}$ and $7.8 \mathrm{ng}$ protein/mL. No test line is evident in control (un-spiked) FVU $(0 \mathrm{ng} / \mathrm{mL})$. The limit of detection of the Afu-LFD ${ }^{\circledR}$ test is therefore estimated to be $\sim 15 \mathrm{ng} A s p f \mathrm{I} / \mathrm{mL}$ urine. (B). Positive test result [control (C) and test (T) lines present] using a urine sample from a patient with acute lymphoid leukaemia and probable IPA. (C) The urine sample was subjected to Western blotting with mAb PD7 and revealed two immuno-reactive proteins with molecular weights of $\sim 19 \mathrm{kDa}$ (labelled 1) and $\sim 12.5 \mathrm{kDa}$ (labelled 2). (D) Replica SDS-PAGE gel of the patient urine stained with Coomassie. Bands corresponding to the immuno-reactive proteins in (C) were excised and subjected to LC-MS analysis. The $\sim 19 \mathrm{kDa}$ protein (labelled 1) was identified as A. fumigatus mitogillin (E), synonymous with A. fumigatus Asp $f$ I. The identity of the $\sim 12.5 \mathrm{kDa}$ protein (labelled 2) could not be established using this technique. 


\section{Discussion}

In this paper, we describe the development and characterisation of an IgG1 monoclonal antibody, PD7, raised against the ribotoxin mitogillin from the human pathogenic mould Aspergillus fumigatus, and its use in urine-based diagnosis of pulmonary aspergillosis, the most important invasive mould disease of humans.

The ribotoxins are a family of ribosome-inactivating proteins (RIPs), which display a highly specific ribonucleolytic activity against a single phosphodiester bond in the universally conserved sarcin/ricin domain of 28 S ribosomal RNA [51,52], and which have been found to be amongst the most potent and specific inhibitors of eukaryotic translation ever recorded $[50,53,54]$. The first members of this family ( $\alpha$-sarcin, restrictocin, and mitogillin) were identified as secreted proteins of Aspergillus giganteus and A. restrictus, and which have potent anti-tumour activity [55]. Subsequently, an $18 \mathrm{kDa}$ IgE-binding allergen from A. fumigatus, Asp $f \mathrm{I}$, was identified as also being a ribotoxin [33], and was shown to be synonymous with restrictocin, since the original strain of $A$. restrictus used to generate restrictocin had been incorrectly identified and was subsequently re-classified as A. fumigatus [56]. Despite this confusion, all Aspergillus ribotoxins share a high degree of sequence and structural similarity [52].

In Western blotting studies of recombinant and native ribotoxins, $\mathrm{mAb}$ PD7 was found to react with $\alpha$-sarcin, restrictocin, mitogillin, $\operatorname{Asp} f \mathrm{I}$, and an $18 \mathrm{kDa}$ antigen secreted by A. fumigatus during growth in liquid culture (this study). Recognition of the different ribotoxins from various sources indicate that the mAb binds to an epitope conserved amongst the proteins. To further investigate the ribotoxin-specific nature of the $\mathrm{mAb}$, we developed mutants of the pathogen that lack ribotoxin production. To do this, we used a split marker recombination procedure for targeted gene replacement of the A. fumigatus mitogillin-encoding gene ( $m i t F$ ) with the hygromycin B phosphotransferase-encoding gene $(h p h)$. This resulted in hygromycin-resistant mutants that lacked production of the $18 \mathrm{kDa}$ ribotoxin, demonstrated by loss of PD7 binding to this antigen in Western blots of culture filtrates, and in colony immunoblots of the mutant strains. In light of these results, and due to previous ambiguities in Aspergillus species identity, we have chosen here to refer to the PD7-reactive ribotoxin produce by A. fumigatus in vitro as Asp $f$ I.

Previous studies pertaining to ribotoxin generation in A. restrictus (nomen ambiguum) suggested that production both in liquid and solid culture is associated with conidiophore formation $[57,58]$. In our studies, we found that $A s p f$ I production by A. fumigatus in liquid culture occurred following spore germination, an observation consistent with previous investigations [32], and that production ended abruptly at $96 \mathrm{~h}$ post-inoculation coincident with hyphal growth cessation. When we compared the dynamics of Asp $f$ I production to that of galactofuranose-rich peptidoglycan molecules recognised by the Aspergillus-specific mAb JF5 [13,59], we found that it was similarly selectively expressed by the growing fungus only but, unlike Galf-containing peptidoglycans, degraded rapidly once sporulation was initiated. Colony immunoblots of the fungus grown on solid medium showed that ribotoxin production, similar to JF5 antigen production, appeared to be associated with the growing margins, but we were unable to determine using this technique whether this might also be due to the differentiation of immature conidiophores. Consequently, to determine whether $A s p f$ I secretion was associated with hyphal proliferation in the absence of sporulation, we investigated its production in a mutant of the pathogen, $\triangle \mathrm{Af} b r \mathrm{~A}$, lacking conidiophores [45]. This mutant, created using insertional mutagenesis, lacks a $\mathrm{C}_{2} \mathrm{H}_{2}$ zinc finger transcription factor that activates expression of genes required for asexual development. When grown in liquid culture, the non-sporulating mutant $\triangle \mathrm{Afbrl} A$ produced $A s p f$ I, with production synchronised to hyphal growth. Taken together, these results show that $A s p f$ I production in A. fumigatus is secreted during active growth of the pathogen. This is advantageous for pathogen detection during progressive lung infection as it is able to discriminate between invasive hyphal growth and sporulation.

Aspergillus fumigatus Asp $f \mathrm{I}$ has no orthologs in the genomes of $A$. nidulans and $A$. oryzae, while the occurrence of a gene in A. terreus with $41 \%$ identity to Asp $f \mathrm{I}$, which 
may be a non-orthologous non-toxin RNAse, has been demonstrated [60]. Using $\mathrm{mAb}$ PD7 in ELISA and Western blotting studies, we did not find ribotoxin production in non-fumigatus Aspergillus species, consistent with other studies [34,35]. While all species assigned to Aspergillus section Clavati have been shown to possess ribotoxin-encoding genes [61], the presence of ribotoxin genes in medically-important sibling species within section Fumigati [62-69] has only been demonstrated in Aspergillus viridinutans and Aspergillus (Neosartorya) fischeri [41]. In ELISA and Western blotting studies using mAb PD7, we demonstrated ribotoxin production in all of the section Fumigati species tested. Consequently, mAb PD7 is specific for A. fumigatus and clinically-important sibling species. Importantly, the $\mathrm{mAb}$ does not cross react with other clinically important mould pathogens.

The hyphal-specific nature of Asp $f$ I production in A. fumigatus makes it an ideal candidate for detecting invasive growth of the pathogen. To exploit this property, and previous observations that the $18 \mathrm{kDa}$ ribotoxin, along with other Aspergillus biomarkers such as galactomannan [70-74] and the iron siderophore TAFC [75], is a major antigen present in the urine of patients and cattle with IPA [24-26], we have used mAb PD7 to develop a lateral-flow assay $\left(A f u\right.$-LFD $\left.{ }^{\circledR}\right)$ which allows single-step and rapid (30 min) detection of the Asp $f$ I biomarker in urine. Unlike Galf-rich peptidoglycans which contain repeat carbohydrate epitopes for detection by mAb JF5 in different sandwich immunoassay formats such as ELISA [10], LFD [59], and proximity ligation assay [76], mAb PD7 binds to a single linear amino acid epitope, which would ordinarily preclude its use in a sandwich immunoassay format. However, the heat-stable nature of the PD7 epitope both in the 18 $\mathrm{kDa}$ monomeric ribotoxin Asp $f$ I and the $36 \mathrm{kDa}$ dimeric ribotoxin mitogillin, enabled us to incorporate a 10 -min heating step at $100{ }^{\circ} \mathrm{C}$ that led to aggregation of the $18 \mathrm{kDa}$ species and subsequent detectability by mAb PD7 in the $A f u$-LFD ${ }^{\circledR}$ test. Heating also served to eliminate non-specific binding in the test with normal human urine (results not shown), a phenomenon similarly shown to improve the specificity of the urinary cryptococcal LFA [77]. Heating combined with a urine concentration step resulted in a limit of detection of $\sim 15 \mathrm{ng} A s p f \mathrm{I} / \mathrm{mL}$ urine. The clinical relevance of this LOD has yet to be determined, but we were nevertheless able to detect the antigen in urine from a patient with acute lymphoid leukaemia diagnosed with probable IPA according to EORTC/MSG criteria. However, further large-scale evaluations of the test need to be performed in order to determine its diagnostic efficacy compared to predicate biomarker tests such as the GM ELISA, and during antifungal treatment which is known to reduce the accuracy of antigen-based tests [2]. A limitation of the test is that it only detects A. fumigatus and other clinically-relevant species in the section Fumigati, but is unable to detect non-fumigatus Aspergillus species (A. flavus, A. nidulans, A. niger, and A. terreus) which also cause IPA in humans.

In conclusion, the non-invasive nature of the test makes it a potential candidate for diagnosing the disease in patients where recovery of invasive bronchoalveolar lavage fluid is not possible, or where transfer of respiratory fluids to the diagnostic laboratory is undesirable due to the presence of highly contagious pathogens such as the SARS-CoV-2 virus [5]. The $A f u$-LFD ${ }^{\circledR}$ test for $A s p f$ I might therefore provide a novel means of identifying A. fumigatus lung infections and, when combined with other urine biomarkers [70-75], might enable improved and ready detection of this devastating disease. While the presence of Asp $f \mathrm{I}$ as a circulating biomarker in the bloodstream of infected patients is currently unknown, further studies will aim to determine its presence in serum. Furthermore, its use as a biomarker of A. fumigatus lung colonisation in other diseases such as ABPA will also be explored.

\section{Trademarks}

The word marks $A f u$-ELISA ${ }^{\circledR}$ and $A f u$-LFD ${ }^{\circledR}$ [UK00003498611 (granted) and EU018319508/018319499 (pending)] are protected by ISCA Diagnostics Ltd. through the UK Intellectual Property Office (UKIPO) and the European Union Intellectual Property Office (EUIPO). 
Supplementary Materials: The following are available online at https://www.mdpi.com/2309-6 08X/7/1/19/s1, Table S1: Details of primers and sequences used for amplification and targeted replacement of the $A$. fumigatus mitogillin-encoding gene mitF. Sequences in bold are the reverse complement of the M13R/M13F overlap, Table S2: Kinetic constants of PD7 binding to mitF from Aspergillus fumigatus (MBS1189059). Kinetic constants were calculated using ForteBio analysis software, fitting a global 1:1 binding model to binding curves (Figure S1A). A good curve fit to this model was determined as $\mathrm{R}^{2}>0.96$ and rate constant error $<20 \%$. $\mathrm{K}_{\mathrm{ON}}=$ Association rate constant; $\mathrm{K}_{\mathrm{OFF}}=$ Dissociation rate constant; $\mathrm{K}_{\mathrm{D}}=$ Equilibrium dissociation constant $\left(\mathrm{K}_{\mathrm{ON}} / \mathrm{K}_{\mathrm{OFF}}\right)$, Figure S1: (A). Binding curves of PD7 to mitF from Aspergillus fumigatus (MBS1189059) using Bio-Layer Interferometry (BLI). Association of mitF at $69.44 \mathrm{nM}$ to $277.8 \mathrm{nM}$ to $50 \mu \mathrm{g} / \mathrm{mL}$ of immobilised PD7 for $60 \mathrm{~s}$, followed by dissociation in PBS for $120 \mathrm{~s}$. Background was corrected by subtraction of values from a PD7 bound biosensor, with association and dissociation steps in PBS alone. (B). PTA-ELISA of mAb PD7 against mitF and Asp $f$ I. With a threshold absorbance value of 0.100 for test positivity, the limit of detection for both mitF and Asp $f$ I was $4 \mathrm{ng} / \mathrm{mL}$, Figure S2: Heat stability the PD7 epitope and protein aggregation. (A). Effect of heat treatment on binding of $\mathrm{mAb}$ PD7 to dimeric mitogillin (mitF) or monomeric Asp $f$ I in PTA-ELISA. There was no significant effect on $\mathrm{mAb}$ binding to mitF over the $60 \mathrm{~min}$ period of heat treatment, whereas heating beyond $30 \mathrm{~min}$ led to a significant progressive reduction in $\mathrm{mAb}$ binding to $A s p f$ I. Each bar is the mean of 3 replicates $\pm \mathrm{SE}$, and bars with the same letters are not significantly different at $p<0.05$. (B). Western blot of heat-treated Asp $f$ I electrophoresed under native conditions. Heating of the ribotoxin led to a progressive increase in $\mathrm{mAb}$ binding indicative of antigen aggregation, Figure S3: Characterisation of ribotoxin-deficient mutants. (A). Agarose gel electrophoresis of PCR products from genomic DNA of the A. fumigatus wild type strain Af293 and nine hygromycin-resistant $\triangle \mathrm{AfmitF}:$ h $p h$ transformants. The products contain both the LF $(0.8-\mathrm{kb})$ and RF $(1.0-\mathrm{kb})$ flanking regions of the mitF gene, with either the mitF gene $(0.5-\mathrm{kb})$ or assembled $h p h$ gene (1.6-kb), with predicted sizes of 2.5-kb for strain Af293 or 3.6-kb for gene replacement mutants. (B). Dry weights of Af293 and two independent mutant strains ( $\triangle \mathrm{AfmitF}:$ :hph2.1 and $\Delta \mathrm{Af} m i t F:: h p h 3.4)$ over the 72-h experimental period. Each data point is the mean of three replicates \pm SE. (C) Western blot of pooled AMM protein samples, showing the presence of the PD7-reactive $18 \mathrm{kDa}$ ribotoxin in Af293, but absence in the two independent mutant strains. (D) Western blot of pooled AMM protein precipitates using $\mathrm{mAb}$ JF5, showing production of galactofuranose-rich peptidoglycans by all isolates (Af293 and mutants). (E) Colony blots of Af293 and mutant strains processed using mAbs PD7 and JF5. PD7-reactive ribotoxin was detectable at the growing edge of the wild type strain, but was absent in both of the mutant strains. Galactofuranose-rich peptidoglycan production, detected using mAb JF5, was similarly associated with the growing edge of colonies of both Af293 and mutant strains. Scale bar $=0.5 \mathrm{~cm}$, Figure S4: Production of the $18 \mathrm{kDa}$ ribotoxin by non-fumigatus Aspergillus species known to cause invasive pulmonary aspergillosis in humans. (A). Dry weights of $A$. fumigatus Af293, three strains of $A$. niger, two strains of $A$. flavus, and a single strain each of $A$. nidulans and $A$. terreus. (B) Absorbance values from $A f u$-ELISA ${ }^{\circledR}$ tests of protein precipitates from 72 -h-old AMM cultures of the fungi, showing no detection of ribotoxin protein in the related species. (C) Western blot of pooled protein samples, showing the absence of the PD7-reactive $18 \mathrm{kDa}$ protein in the related species, and in the negative control (AMM only). Bars in (A) and (B) are the means of 3 replicate values $\pm \mathrm{SE}$, and bars with the same letter are not significantly different at $p<0.05$. The threshold absorbance value for detection of ribotoxin protein in the $A f u$-ELISA ${ }^{\circledR}(B)$ is $\geq 0.100$, Figure S5: Production of the $18 \mathrm{kDa}$ ribotoxin by sibling species in the Aspergillus Section Fumigati known to cause invasive pulmonary aspergillosis in humans. (A). Dry weights of A. fumigatus Af293 and sibling species. (B) Absorbance values from $A f u$-ELISA ${ }^{\circledR}$ tests of protein precipitates from 72-h-old AMM cultures of the fungi, showing detection of the protein in A. lentulus, N. pseudofischeri (A. thermomutatus), A. viridinutans, N. fischeri, and A. fumigatiaffinis. (C) Western blot of pooled protein samples, showing the presence of the PD7-reactive $18 \mathrm{kDa}$ ribotoxin in A. lentulus, N. pseudofischeri, A. viridinutans, N. fischeri, and A. fumigatiaffinis. No ribotoxin was detected in $A$. udugawae, but an additional higher molecular weight band, a putative dimer of $\sim 36 \mathrm{kDa}$, was evident in A. fumigatiaffinis. Bars in (A) and $(B)$ are the means of 3 replicate values $\pm S E$, and bars with the same letter are not significantly different at $p<0.05$. The threshold absorbance value for detection of antigen in the Afu-ELISA ${ }^{\circledR}$ (B) is $\geq 0.100$, Figure S6: Ribotoxin production during extended growth of the sibling species Aspergillus udagawae and Aspergillus fumigatiaffinis. (A) Dry weights of sibling strains and the positive control strain A. fumigatus Af293. (B) Absorbance values for $A f u$-ELISA ${ }^{\circledR}$ tests of protein precipitates of AMM culture filtrates for the three strains at the different time points. (C) Western blot of pooled 


\begin{abstract}
AMM protein precipitates for Af293 at each time point. (D) Western blot of pooled AMM protein precipitates for A. udagawae at each time point (E) Western blot of pooled AMM protein precipitates for $A$. fumigatiaffinis at each time point. Note the presence of single PD7-reactive $18 \mathrm{kDa}$ proteins in all three species, and the presence of an additional higher molecular weight PD7-reactive protein (a putative $\sim 36 \mathrm{kDa}$ dimer) in the pooled 96-h-old samples from A. fumigatiaffinis. Data points in (A) and (B) are the means of 3 replicate values \pm Se, Figure S7: Production of the $18 \mathrm{kDa}$ ribotoxin by unrelated but clinically important moulds pathogenic to humans. (A). Dry weights of A. fumigatus Af293 and the unrelated pathogens. (B). Absorbance values from $A f u$-ELISA ${ }^{\circledR}$ tests of protein precipitates from 72-h-old MEB cultures of the fungi, showing no detection of the $18 \mathrm{kDa}$ protein in the unrelated species. (C) Western blot of pooled protein samples, showing the absence of the PD7-reactive $18 \mathrm{kDa}$ antigen in the unrelated species, and in the negative control (MEB only). Bars in (A) and (B) are the means of 3 replicate values $\pm \mathrm{SE}$, and bars with the same letter are not significantly different at $p<$ 0.05 . The threshold absorbance value for detection of protein in the $A f u$-ELISA ${ }^{\circledR}$ (B) is $\geq 0.100$.
\end{abstract}

Author Contributions: Conceptualisation, C.R.T. and G.D.; methodology, C.R.T. and G.D.; investigation, C.R.T., G.D. and O.S.; formal analysis, G.D. and O.S.; resources, C.R.T., J.P. and M.H.; data curation, C.R.T., G.D. and O.S.; writing—original draft preparation, C.R.T. and G.D.; writing, review and editing, C.R.T., G.D., J.P., M.H. and P.W.S.; supervision, C.R.T. and G.D.; project administration, C.R.T.; funding acquisition, C.R.T. and P.W.S. All authors have read and agreed to the published version of the manuscript.

Funding: This work was supported by a grant to ISCA Diagnostics Ltd. by Innovate UK (file reference 105440), to whom we are grateful.

Informed Consent Statement: Informed consent was obtained from all subjects in this study.

Data Availability Statement: The data presented in this study are available on request from the corresponding author. The data are not publicly available due to commercial confidentialities.

Conflicts of Interest: C.R. Thornton is a Director of ISCA Diagnostics Ltd. M. Hoenigl has received research funding from Gilead and Pfizer outside of this work. The other authors declare no conflicts of interest.

\title{
References
}

1. Latgé, J.-P.; Chamilos, G. Aspergillus fumigatus and Aspergillosis in 2019. Clin. Microbiol. Rev. 2019, 33, e00140-18.

2. Thornton, C.R. Detection of the 'Big Five' mould killers of humans: Aspergillus, Fusarium, Lomentospora, Scedosporium and Mucormycetes. Adv. Appl. Microbiol. 2020, 110, 1-61. [PubMed]

3. Alanio, A.; Dellièrre, S.; Fodil, S.; Bretagne, S.; Mégarbane, B. Prevalence of putative aspergillosis in critically ill patients with COVID-19. Lancet Infect. Dis. 2020, 8, e48-e49.

4. Arastehfar, A.; Carvalho, A.; van de Veerdonk, F.L.; Jenks, J.D.; Koehler, P.; Krause, R.; Cornely, O.A.; Perlin, D.S.; Lass-Florl, C.; Hoenigl, M. COVID-19 Associated Pulmonary Aspergillosis (CAPA)—From immunology to treatment. J. Fungi 2020, 6, 91. [CrossRef]

5. Prattes, J.; Valentin, T.; Hoenigl, M.; Talakic, E.; Reisinger, A.C.; Eller, P. Invasive pulmonary aspergillosis complicating COVID-19 in the ICU-A case report. Med. Mycol. Case Rep. 2020, in press. [CrossRef]

6. Schauwvlieghe, A.F.A.D.; Rijnders, B.J.A.; Philips, N.; Verwijs, R.; Vanderbeke, L.; Van Tienen, C.; Lagrou, K.; Verweij, P.E.; Van de Veerdonk, F.L.; Gommers, D.; et al. Invasive aspergillosis in patients admitted to the intensive care unit with severe influenza: A retrospective cohort study. Lancet Respir. Med. 2018, 6, 782-792. [CrossRef]

7. Wauters, J.; Baar, I.; Meersseman, P.; Meersseman, W.; Dams, K.; De Paep, R.; Lagrou, K.; Wilmer, A.; Jorens, P.; Herman, G. Invasive pulmonary aspergillosis is a frequent complication of critically ill H1N1 patients: A retrospective study. Intensive Care Med. 2012, 38, 1761-1768. [CrossRef]

8. Bongomin, F.; Gago, S.; Oladele, R.; Denning, D. Global and multi-national prevalence of fungal diseases-estimate precision. J. Fungi 2017, 3, 57. [CrossRef]

9. Donnelly, P.J.; Chen, S.C.; Kauffman, C.A.; Steinbach, W.J.; Baddley, J.W.; Verweij, P.E.; Clancy, C.J.; Wingard, J.R.; Lockhart, S.R.; Groll, A.H.; et al. Revision and update of the consensus definitions of invasive fungal disease from the European organisation for research and treatment of cancer and the mycoses study group education and research consortium. Clin. Infect. Dis. 2020, 71, 1367-1376. [CrossRef]

10. Dichtl, K.; Seybold, U.; Ormanns, S.; Horns, H.; Wagener, J. Evaluation of a novel Aspergillus antigen ELISA. J. Clin. Microbiol. 2019, 57, e00136-19. [CrossRef]

11. Mercier, T.; Schauwvlieghe, A.; de Kort, E.; Dunbar, A.; Reynders, M.; Guldentops, E.; Rijnders, B.; Verweij, P.E.; Lagrou, K.; Maertens, J. Diagnosing invasive pulmonary aspergillosis in hematology patients: A retrospective multicentre evaluation of a novel lateral flow device. J. Clin. Microbiol. 2019, 57, e01913-18. [CrossRef] [PubMed] 
12. Thornton, C.R. Molecular imaging of invasive pulmonary aspergillosis using immunoPET/MRI: The future looks bright. Front. Microbiol. 2018, 9, 691. [CrossRef] [PubMed]

13. Davies, G.; Rolle, A.-M.; Maurer, A.; Spycher, P.R.; Schillinger, C.; Solouk-Saran, D.; Hasenberg, M.; Weski, J.; Fonslet, J.; Dubois, A.; et al. Towards translational immunoPET/MR imaging of invasive pulmonary aspergillosis: The humanised monoclonal antibody JF5 detects Aspergillus lung infections in vivo. Theranostics 2017, 11, 3398-3414. [CrossRef] [PubMed]

14. Rolle, A.-M.; Hasenberg, M.; Thornton, C.R.; Solouk-Saran, D.; Männ, L.; Weski, J.; Maurer, A.; Fischer, E.; Spycher, P.R.; Boschetti, F.; et al. ImmunoPET/MR imaging allows specific detection of Aspergillus lung infection in vivo. Proc. Natl. Acad. Sci. USA 2016, 113, E1026-E1033. [CrossRef]

15. Adachi, J.; Kumar, C.; Zhang, Y.; Olsen, J.V.; Mann, M. The human urinary proteome contains more than 1500 proteins, including a large proportion of membrane proteins. Genome Biol. 2006, 7, R80. [CrossRef]

16. Thomas, C.E.; Sexton, W.; Benson, K.; Sutphen, R.; Koomen, J. Urine collection and processing for protein biomarker discovery and quantification. Cancer Epidemiol. Biomarkers Prev. 2010, 19, 953-959. [CrossRef]

17. Pride, M.W.; Huijts, S.M.; Wu, K.; Souza, V.; Passador, S.; Tinder, C.; Song, E.; Elfassy, A.; McNeil, L.; Menton, R.; et al. Validation of an immunodiagnostic assay for detection of 13 Streptococcus pneumoniae serotype-specific polysaccharides in human urine. Clin. Vacc. Immunol. 2012, 19, 1131-1141. [CrossRef]

18. Bosompem, K.M.; Arishima, T.; Yamashita, T.; Ayi, I.; Anyan, W.K.; Kojima, S. Extraction of Schistosoma haematobium antigens from infected human urine and generation of potential diagnostic monoclonal antibodies to urinary antigens. Acta Trop. 1996, 62, 91-103. [CrossRef]

19. Bosompem, K.M.; Ayi, I.; Anyan, W.K.; Arishima, T.; Nkrumah, F.K.; Kojima, S. A monoclonal antibody-based dipstick assay for diagnosis of urinary schistosomiasis. Trans. R. Soc. Trop. Med. Hyg. 1997, 91, 554-556. [CrossRef]

20. Shirey, R.J.; Globisch, D.; Eubanks, L.M.; Hixon, M.S.; Janda, K.D. Non-invasive urine biomarker lateral flow immunoassay for monitoring active onchocerciasis. ACS Infect. Dis. 2018, 4, 1423-1431. [CrossRef]

21. Shurley, J.F.; Legendre, A.M.; Scalarone, G.M. Blastomyces dermatitidis antigen detection in urine specimens from dogs with blastomycosis using a competitive binding inhibition ELISA. Mycopathologia 2005, 160, 137-142. [CrossRef] [PubMed]

22. Libert, D.; Procop, G.W.; Ansari, M.Q. Histoplasma urinary antigen testing obviates the need for coincident serum antigen testing. Am. J. Clin. Pathol. 2018, 149, 362-368. [CrossRef] [PubMed]

23. Marr, K.A.; Datta, K.; Mehta, S.; Ostrander, D.B.; Rock, M.; Francis, J.; Feldmesser, M. Urine antigen detection as an aid to diagnose invasive aspergillosis. Clin. Infect. Dis. 2018, 67, 1705-1711. [CrossRef] [PubMed]

24. Haynes, K.A.; Latgé, J.-P.; Rogers, T.R. Detection of Aspergillus antigens associated with invasive aspergillosis. J. Clin. Microbiol. 1990, 28, 2040-2044. [CrossRef]

25. Jensen, H.E.; Stynen, D.; Sarfati, J.; Latgé, J.-P. Detection of galactomannan and the 18kDa antigen from Aspergillus fumigatus in serum and urine from cattle with systemic aspergillosis. J. Vet. Med. B 1993, 40, 397-408. [CrossRef]

26. Latgé, J.-P.; Moutaouakil, M.; Debeaupuis, J.-P.; Bouchara, J.-P.; Haynes, K.; Prévost, M.-C. The 18-kilodalton antigen secreted by Aspergillus fumigatus. Infect. Immun. 1991, 59, 2586-2594.

27. Kao, R.; Martínez-Ruiz, A.; Martínez del Pozo, A.; Crameri, R.; Davies, J. Mitogillin and related fungal ribotoxins. Methods Enzymol. 2001, 341, 324-335.

28. Olombrada, M.; Lázaro-Gorines, R.; López-Rodríguez, J.C.; Martínez-del-Pozo, A.; Oñaderra, M.; Maestro-López, M.; Lacadena, J.; Gavilanes, J.G.; García-Ortega, L. Fungal ribotoxins: A review of potential biotechnological applications. Toxins 2017,9 , 71. [CrossRef]

29. López-Otin, C.; Barber, D.; Fernandez-Luna, J.L.; Soriano, F.; Mendez, E. The primary structure of the cytotoxin restrictocin. Eur. J. Biochem. 1984, 143, 621-634. [CrossRef]

30. Oka, T.; Natori, Y.; Tanaka, S.; Tsurugi, K.; Endo, Y. Complete nucleotide sequence of cDNA for the cytotoxin alpha sarcin. Nucleic Acids Res. 1990, 18, 1897. [CrossRef]

31. Huang, K.-C.; Hwang, Y.-Y.; Hwu, L.; Lin, A. Characterisation of a new ribotoxin gene (c-sar) from Aspergillus clavatus. Toxicon 1997, 35, 383-392. [CrossRef]

32. Arruda, L.K.; Platts-Mills, T.A.E.; Longbottom, J.L.; El-Dahr, J.M.; Chapman, M.D. Aspergillus fumigatus: Identification of 16kd, $18 \mathrm{kd}$ and $45 \mathrm{kd}$ antigens recognised by human IgG and IgE antibodies and murine monoclonal antibodies. J. Allergy Clin. Immunol. 1992, 89, 1166-1176. [CrossRef]

33. Moser, M.; Crameri, R.; Menz, G.; Schneider, T.; Dudler, T.; Virchow, C.; Gmachl, M.; Blaser, K.; Suter, M. Cloning and expression of recombinant Aspergillus fumigatus allergen I/a (rAsp f I/a) with IgE binding and type I skin test activity. J. Immunol. 1992, 149, 454-460.

34. Arruda, L.K.; Platts-Mills, T.A.E.; Fox, J.W.; Chapman, M.D. Aspergillus fumigatus allergen I, a major IgE-binding protein, is a member of the mitogillin family of cytotoxins. J. Exp. Med. 1990, 172, 1529-1532. [CrossRef] [PubMed]

35. Arruda, L.K.; Mann, B.J.; Chapman, M.D. Selective expression of a major allergen and cytotoxin, Asp $f$ I, in Aspergillus fumigatus. Implications for the immunopathogenesis of Aspergillus-related diseases. J. Immunol. 1992, 149, 3354-3359. [PubMed]

36. Banerjee, B.; Greenberger, P.A.; Fink, J.N.; Kurup, V.P. Molecular characterisation of Aspergillus fumigatus allergens. Indian, J. Chest Dis. Allied Sci. 2000, 42, 239-248.

37. Crameri, R.; Garbani, M.; Rhyner, C.; Huitema, C. Fungi: The neglected allergenic sources. Allergy 2014, 69, 176-185. [CrossRef] [PubMed] 
38. El-Dahr, J.M.; Fink, R.; Selden, R.; Arruda, L.K.; Platts-Mills, T.A.; Heymann, P.W. Development of immune responses to Aspergillus at an early stage in children with cystic fibrosis. Am. J. Respir. Crit. Care Med. 1994, 150, 1513-1518. [CrossRef]

39. Takazono, T.; Sheppard, D.C. Aspergillus in chronic lung disease: Modelling what goes on in the airways. Med. Mycol. 2017, 5, 39-47. [CrossRef]

40. Dos Santos, R.A.C.; Steenwyk, J.L.; Rivero-Menendez, O.; Mead, M.E.; Silva, L.P.; Bastos, R.W.; Alastruey-Izquierdo, A.; Goldman, G.H.; Rokas, A. Genomic and phenotypic heterogeneity of clinical isolates of the human pathogens Aspergillus fumigatus, Aspergillus lentulus, and Aspergillus fumigatiaffinis. Front. Genet. 2020, 11, 459. [CrossRef]

41. Martínez-Ruiz, A.; Kao, R.; Davies, J.; Martínez del Pozo, A. Ribotoxins are a more widespread group of proteins within the filamentous fungi than previously believed. Toxicon 1999, 37, 1549-1563. [CrossRef]

42. Van der Linden, J.W.M.; Warris, A.; Verweij, P.E. Aspergillus species intrinsically resistant to antifungal drugs. Med. Mycol. 2011, 49, S82-S89. [CrossRef] [PubMed]

43. Thornton, C.R. Immunological Methods for Fungi. In Molecular and Cellular Biology of Filamentous Fungi: A Practical Approach, 1st ed.; Talbot, N.J., Ed.; Oxford University Press: Oxford, UK, 2001; pp. 227-256.

44. Garcia, M.E.; Blanco, J.L.; Kurup, V.P. Identification of Aspergillus fumigatus by PCR. Rev. Iberoam. Micol. 1998, 15, 25-27. [PubMed]

45. Mah, J.-E.; Yu, J.-H. Upstream and downstream regulation of asexual development in Aspergillus fumigatus. Euk. Cell 2006, 5, 1585-1595. [CrossRef] [PubMed]

46. McCluskey, K. The fungal genetics stock center: From molds to molecules. Adv. Appl. Microbiol. 2003, 52, 245-260. [PubMed]

47. Catlett, N.L.; Lee, B.-E.; Yoder, O.C.; Turgeon, B.G. Split-marker recombination for efficient targeted deletion of fungal genes. Fungal Genet. Newsl. 2003, 50, 9-11. [CrossRef]

48. Thornton, C.R.; Ryder, L.S.; Le Cocq, K.; Soanes, D.M. Identifying the emerging human pathogen Scedosporium prolificans by using a species-specific monoclonal antibody that binds to the melanin biosynthetic enzyme tetrahydroxynaphthalene reductase. Environ. Microbiol. 2015, 17, 1023-1038. [CrossRef]

49. Schwienbacher, M.; Weig, M.; Thies, S.; Regula, J.T.; Heesemann, J.; Ebel, F. Analysis of the major proteins secreted by the human opportunistic pathogen Aspergillus fumigatus under in vitro conditions. Med. Mycol. 2005, 43, 623-630. [CrossRef]

50. Fando, J.L.; Alaba, I.; Escarmis, C.; Fernandez-Luna, J.L.; Mendez, E.; Salinas, M. The mode of action of restrictocin and mitogillin in eukaryotic ribosomes. Eur. J. Biochem. 1985, 149, 29-34. [CrossRef]

51. Kao, R.; Davies, J. Fungal ribotoxins: A family of naturally engineered targeted toxins? Biochem. Cell Biol. 1995, 73, 1151-1159. [CrossRef]

52. Lacadena, J.; Álvarez-García, E.; Carreras-Sangrà, N.; Herrero-Galán, E.; Alegre-Cebollada, J.; García-Ortega, L.; Oñaderra, M.; Gavilanes, J.G.; Martínez del Pozo, A. Fungal ribotoxins: Molecular dissection of a family of natural killers. FEMS Microbiol. Rev. 2007, 31, 212-237. [CrossRef] [PubMed]

53. Fernandez-Puentes, C.; Vazquez, D. Effects of some proteins that inactivate the eukaryotic ribosome. FEBS Lett. 1977, 78, 143-146. [CrossRef]

54. Jimenez, A.; Vazquez, D. Plant and fungal protein and glycoprotein toxins inhibiting eukaryote protein synthesis. Annu. Rev. Microbiol. 1985, 39, 649-672. [CrossRef] [PubMed]

55. Olson, B.H.; Goerner, G.L. Alpha-sarcin, a new antitumor agent, I. Isolation, purification, chemical composition, and the identity of a new amino acid. Appl. Microbiol. 1965, 13, 314-321. [CrossRef]

56. Lamy, B.; Moutaouakil, M.; Latgé, J.-P.; Davies, J. Secretion of a potential virulence factor, a fungal ribonucleotoxin, during human aspergillosis infections. Mol. Microbiol. 1991, 5, 1811-1815. [CrossRef]

57. Brandhorst, T.T.; Kenealy, W.R. Production and localisation or restrictocin in Aspergillus restrictus. J. Gen. Microbiol. 1992, 138, 1429-1435. [CrossRef]

58. Yang, R.; Kenealy, W.R. Regulation of restrictocin production in Aspergillus restrictus. J. Gen. Microbiol. 1992, 138, 1421-1427. [CrossRef]

59. Thornton, C.R. Development of an immunochromatographic lateral-flow device for rapid serodiagnosis of invasive aspergillosis. Clin. Vaccine Immunol. 2008, 15, 1095-1105. [CrossRef]

60. Bowyer, P.; Fraczek, M.; Denning, D.W. Comparative genomics of fungal allergens and epitopes show widespread distribution of closely related antigen and epitope orthologues. BMC Genom. 2006, 7, 251. [CrossRef] [PubMed]

61. Varga, J.; Samson, R.A. Ribotoxin genes in isolates of Aspergillus section Clavati. Antonie Leeuwenhoek 2008, 94, 481-485. [CrossRef]

62. Balajee, S.A.; Gribskov, J.; Brandt, M.; Ito, J.; Fothergill, A.; Marr, K.A. Mistaken identity: Neosartorya pseudofischeri and its anamorph masquerading as Aspergillus fumigatus. J. Clin. Microbiol. 2005, 43, 5996-5999. [CrossRef] [PubMed]

63. Coelho, D.; Silva, S.; Vale-Silva, L.; Gomes, H.; Pinto, E.; Sarmento, A.; Pinheiro, M.A. Aspergillus viridinutans: An agent of adult chronic invasive aspergillosis. Med. Mycol. 2011, 49, 755-759. [CrossRef] [PubMed]

64. Järv, H.; Lehtmaan, J.; Summerbell, R.C.; Hoekstra, E.S.; Samson, R.A.; Naaber, P. Isolation of Neosartorya pseudofischeri from blood: First hint of pulmonary aspergillosis. J. Clin. Microbiol. 2004, 42, 925-928. [CrossRef] [PubMed]

65. Lamoth, F. Aspergillus fumigatus-related species in clinical practice. Front. Microbiol. 2016, 7, 683. [CrossRef]

66. Larsen, T.O.; Smedsgaard, J.; Nielsen, K.F.; Hansen, M.A.E.; Samson, R.A.; Frisvad, J.C. Production of mycotoxins by Aspergillus lentulus and other medically important and closely related species in section Fumigati. Med. Mycol. 2007, 45, 225-232. [CrossRef]

67. Lonial, S.; Williams, L.; Carrum, G.; Ostrowski, M.; McCarthy, P. Neosartorya fischeri: An invasive fungal pathogen in an allogeneic bone marrow transplant patient. Bone Marrow Transplant. 1997, 19, 753-755. [CrossRef] 
68. Sugui, J.A.; Vinh, D.C.; Nardone, G.; Shea, Y.R.; Chang, Y.C.; Zelazny, A.M.; Marr, K.A.; Holland, S.M.; Kwon-Chung, K.J. Neosartorya udagawae (Aspergillus udagawae), an emerging agent of aspergillosis: How different is it from Aspergillus fumigatus? J. Clin. Microbiol. 2010, 48, 220-228. [CrossRef]

69. Yaguchi, T.; Horie, Y.; Tanaki, R.; Matsuzawa, T.; Ito, J.; Nishimura, K. Molecular phylogenetics of multiple genes on Aspergillus section Fumigati isolated from clinical specimens in Japan. Jpn. J. Med. Mycol. 2007, 48, 37-46. [CrossRef]

70. Ansorg, R.; von Heinegg, E.H.; Rath, P.M. Aspergillus antigenuria compared to antigenemia in bone marrow transplant recipients. Eur. J. Clin. Microbiol. Infect. Dis. 1994, 13, 582-589. [CrossRef]

71. Dufresene, S.F.; Datta, K.; Li, X.; Dadachova, E.; Staab, J.F.; Patterson, T.F.; Feldmesser, M.; Marr, K.A. Detection of urinary excreted fungal galactomannan-like antigens for diagnosis of invasive aspergillosis. PLoS ONE 2012, 7, e42736. [CrossRef]

72. Dupont, B.; Huber, M.; Kim, S.J.; Bennett, J.E. Galactomannan antigenemia and antigenuria in aspergillosis: Studies in patients and experimentally infected rabbits. J. Infect. Dis. 1987, 155, 1-11. [CrossRef] [PubMed]

73. Reischies, F.M.J.; Raggam, R.B.; Prattes, J.; Krause, R.; Eigl, S.; List, S.; Quehenberger, F.; Strenger, V.; Wölfler, A.; Hoenigl, M. Urine galactomannan-to-creatinine ratio for detection of invasive aspergillosis in patients with hematological malignancies. $J$. Clin. Microbiol. 2016, 54, 771-774. [CrossRef] [PubMed]

74. Salonen, J.; Lehtonen, O.-P.; Teräsjärvi, M.-R.; Nikoskelainen, J. Aspergillus antigen in serum, urine and bronchoalveolar lavage specimens of neutropenic patients in relation to clinical outcome. Scand. J. Infect. Dis. 2000, 32, 485-490. [PubMed]

75. Hoenigl, M.; Orasch, T.; Faserl, K.; Prattes, J.; Loeffler, J.; Springer, J.; Gsaller, F.; Reischies, F.; Duettmann, W.; Raggam, R.B.; et al. Triacetylfusarinine C: A urine biomarker for diagnosis of invasive aspergillosis. J. Infect. 2019, 78, 150-157. [CrossRef]

76. Johnson, G.L.; Shanon, M.; Thornton, C.; Agrawal, S.G.; Bustin, S.A. Proximity ligation assay for the sensitive, specific and early detection of invasive fungal disease. Mycoses 2013, 56, 48-49.

77. Brito-Santos, F.; de Faria Ferreira, M.; Trilles, L.; de Medeiros Muniz, M.; dos Santos, V.G.V.; Carvalho-Costa, F.A.; Meyer, W.; Wanke, B.; dos Santos Lazéra, M. Preheating of urine improves the specificity of cryptococcal antigen testing using the lateral flow assay. PLoS Negl. Trop. Dis. 2017, 11, e0005304. [CrossRef] 